
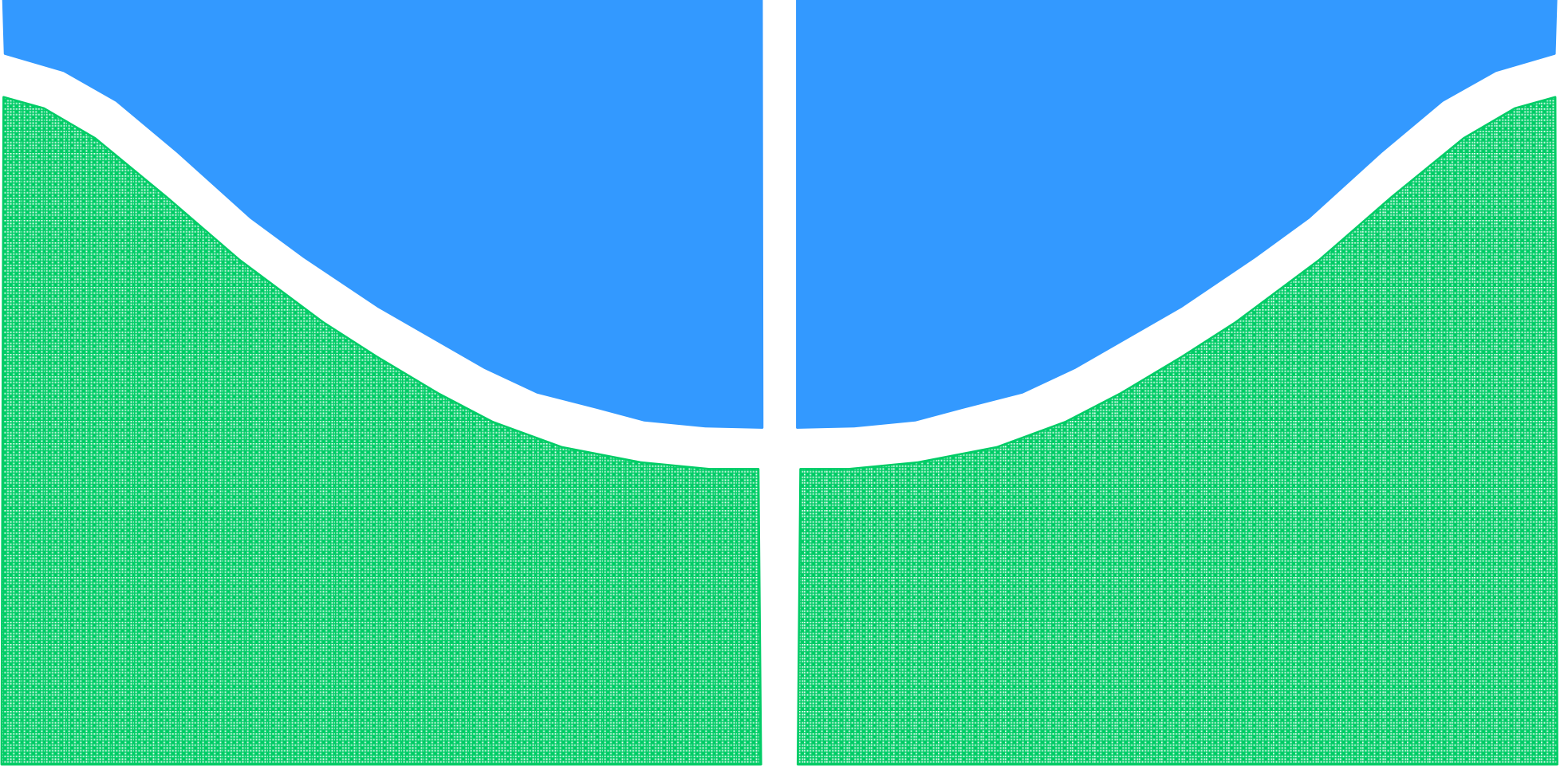

TRABALHO DE GRADUAÇÃO

\title{
ESTUDO DE MÚLTIPLAS ANTENAS PARA SISTEMAS DE COMUNICAÇÃO MÓVEL
}

Marcelo Silveira Kessler 
UNIVERSIDADE DE BRASILIA

Faculdade de Tecnologia

\title{
TRABALHO DE GRADUAÇÃO
}

\section{ESTUDO DE MÚLTIPLAS ANTENAS PARA SISTEMAS DE COMUNICAÇÃO MÓVEL}

\author{
Marcelo Silveira Kessler \\ Relatório submetido as Departamento de Engenharia Elétrica \\ da Universidade de Brasília como requisito parcial para \\ obtenção do grau de Engenheiro Eletricista
}

\section{Banca Examinadora}

Prof. Dr. Antônio José Martins Soares, ENE/UnB Orientador

Prof. Dr. Franklin da Costa Silva, ENE/UnB

Examinador

Prof. Dr. Plínio Ricardo Ganime Alves, ENE/UnB

Examinador 


\section{Dedicatória}

Dedico a todos que, de alguma maneira, me ajudaram ou incentivaram em seu desenvolvimento.

Marcelo Silveira Kessler 


\section{Agradecimentos}

Em primeiro lugar, a Deus, por toda a força e perseverança que me proporcionaram vivenciar esse momento.

Aos meus pais e à minha irmã Lígia, que me deram os princípios necessários acompanhados de muito carinho e amizade, servindo de exemplo constante durante toda a caminhada.

À minha namorada Maitê, ao meu lado durante toda a jornada me apoiando e incentivando em todos os instantes.

A todos os meus amigos e colegas de curso, que fizeram desse árduo caminho uma festa de proporções imensuráveis, balanceando seriedade e diversão e fazendo desse período uma experiência inesquecível.

Por fim, ao professor Martins, por compartilhar seu nobre conhecimento e tornar possível o aprendizado enorme que foi o desenvolvimento deste trabalho.

Marcelo Silveira Kessler 


\section{RESUMO}

Novas tecnologias têm sido desenvolvidas no sentido de prover com maior eficiência e capacidade as necessidades de sistemas sem fios. Dentre essas, uma que merece destaque é a tecnologia MIMO, que envolve múltiplas antenas nas extremidades do enlace permitindo o alcance de maiores taxas de transmissão e maior confiabilidade.

Este trabalho apresenta um estudo teórico e prático sobre sistemas multi-antena, descrevendo conceitos característicos da tecnologia MIMO e da teoria de antenas. Realizado o estudo preliminar, simulações de estruturas contento múltiplas antenas no software FDTDStudio são apresentadas para avaliar o acoplamento mútuo entre antenas em diferentes cenários. Por fim, uma estrutura indicada para dispositivos móveis celulares foi simulada, construída e testada, confirmando a teoria apresentada e validando os aspectos abordados no trabalho.

\section{ABSTRACT}

New technologies have been developed to provide greater efficiency and capacity of the needs of wireless systems. Among these, one that deserves mention is the MIMO technology, which involves multiple antennas at the ends of the channel link enabling the achievement of higher data rates and greater reliability.

This paper presents a theoretical and practical understanding of multi-antenna systems, describing the concepts of MIMO and antenna theory. Performed the preliminary study, simulations of structures with multiple antennas in the FDTDStudio software are presented to demonstrate the mutual coupling between antennas in different scenarios. Finally, a structure indicated for mobile phones was simulated, built and tested, confirming the theory presented and validating those aspects approached in the work. 


\section{SUMÁRIO}

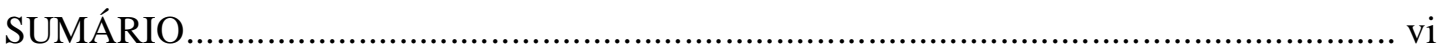

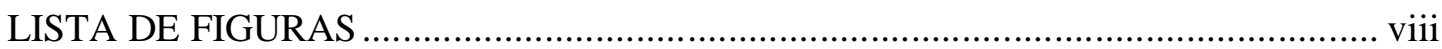

LISTA DE SIGLAS

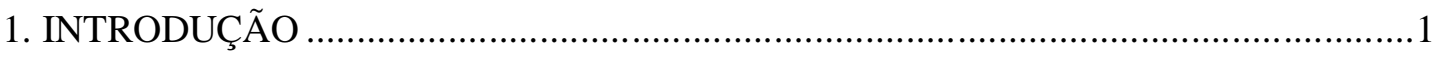

2. TECNOLOGIA MIMO

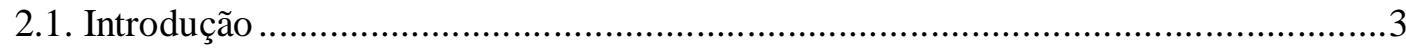

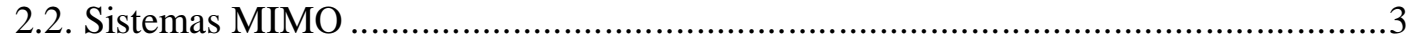

2.3. Vantagens do Sistema MIMO ..........................................................................

2.3.1. Ganho de Arranjo ………………………………….................................

2.3.2. Diversidade Espacial .............................................................................

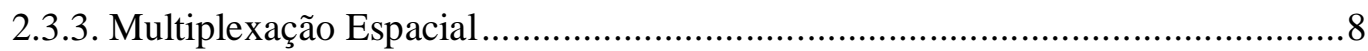

2.4. Decomposição em Paralelo do Canal MIMO ………….........................................

2.4.1. Compromisso entre Multiplexação e Diversidade ………………………..........11

2.5. Capacidade do Canal MIMO ……………………............................................13

2.6. Limitações do Sistema MIMO ...............................................................................14

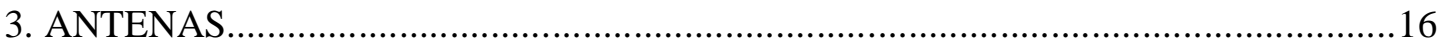

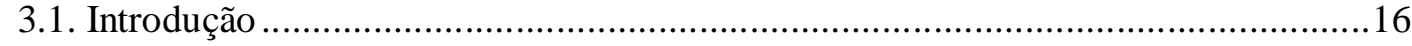

3.2. Conceitos Básicos .....................................................................................17

3.2.1. Regiões de Ação das Antenas ...................................................................17

3.2.2. Parâmetros do Diagrama de Radiação .............................................................18

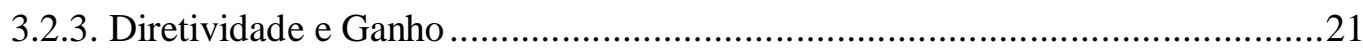

3.2.4. Impedância de Entrada....................................................................................21

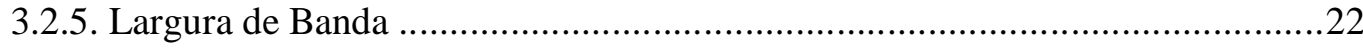

3.2.6. Tipos de Polarização................................................................................22

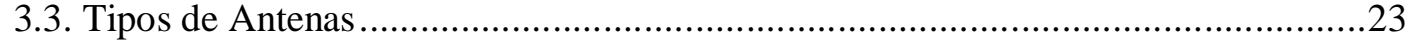

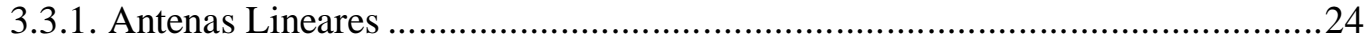

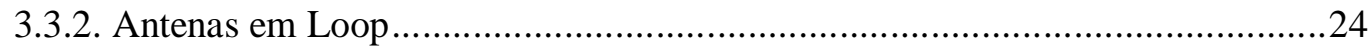

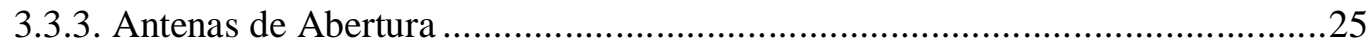

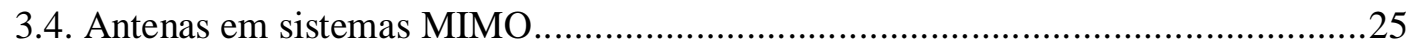

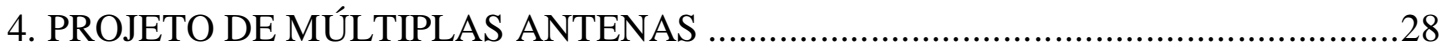




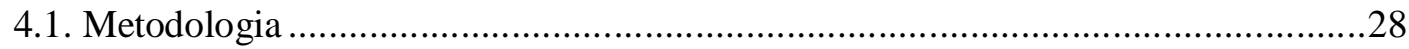

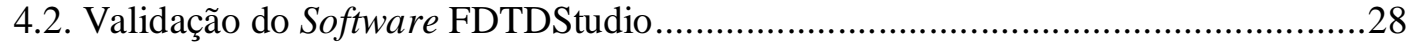

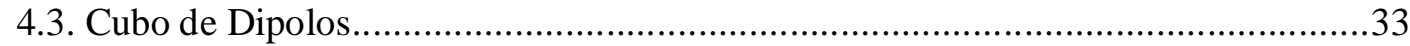

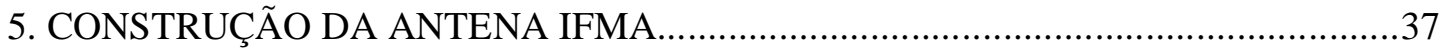

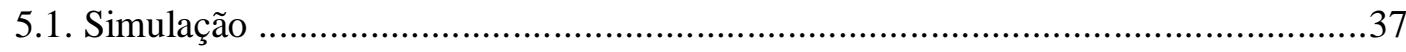

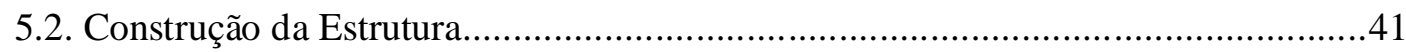

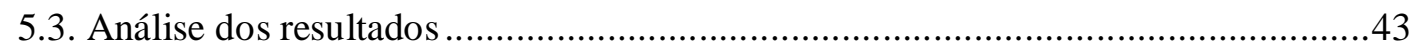

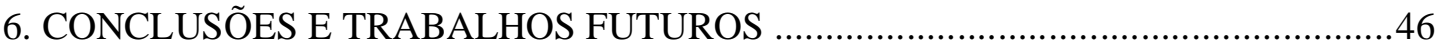

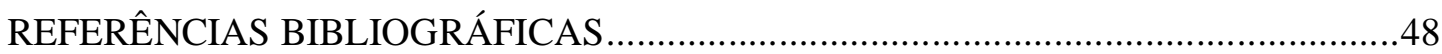




\section{LISTA DE FIGURAS}

Figura 2.1 - Sistema MIMO simplificado .......................................................................... 4

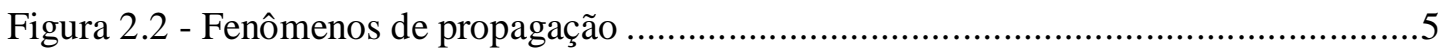

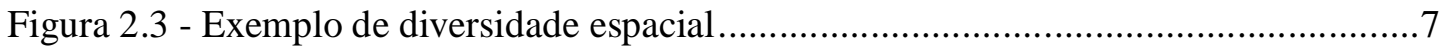

Figura 2.4 - Formação de feixe (beamforming) do sinal transmitido ..................................

Figura 2.5 - Técnicas de transmissão em sistemas MIMO …........................................

Figura 2.6 - Processamento dos dados nos sistemas transmissor e receptor.......................10

Figura 2.7 - Resultado da decomposição em paralelo de um canal MIMO ........................11

Figura 2.8 - Compromisso entre multiplexação e diversidade ..........................................12

Figura 3.1 - Mecanismo de radiação de uma antena........................................................16

Figura 3.2 - Regiões de ação das antenas..................................................................... 18

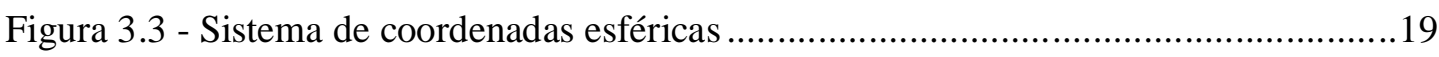

Figura 3.4 - Plano E do dipolo ideal e sua rotação em eixo de simetria .............................19

Figura 3.5 - Lóbulo principal, lóbulos laterais e feixe de meia potência ............................20

Figura 3.6 - Diretividade em relação à antena isotrópica...............................................21

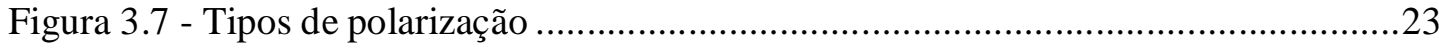

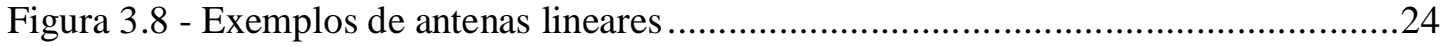

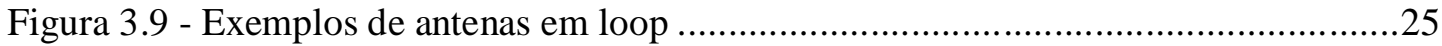

Figura 3.10 - Configurações de antenas de abertura.......................................................25

Figura 3.11 - Antenas utilizadas na telefonia celular...................................................26

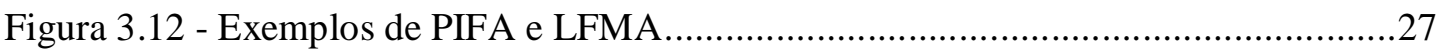

Figura 4.1 - Dois dipolos paralelos, posicionados lado a lado ........................................29

Figura 4.2 - Dois dipolos paralelos na interface do FDTDStudio ..................................... 30

Figura 4.3 - Valores simulados e calculados de Impedância Mútua ...................................31

Figura 4.4 - Impedância de dipolo isolado e de dipolos separados por $d=0,2 \lambda \ldots \ldots \ldots \ldots \ldots . . .31$

Figura 4.5 - Diagramas de radiação de dipolo isolado e de dipolos separados $d=0,2 \lambda \ldots . .32$

Figura 4.6 - Perdas de retorno para dipolo isolado e para dipolos separados por $d=0,2 \lambda . .33$

Figura 4.7 - Relação entre tensões na entrada e no terminal dos transmissores...................34

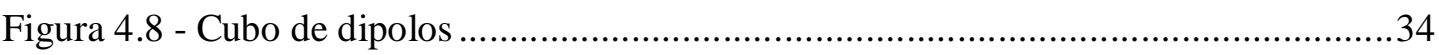

Figura 4.9 - Passos da simulação para determinação da matriz de impedância ...................35

Figura 4.10 - Esboço da matriz de impedância do cubo de dipolos ..................................36 
Figura 5.1 - Geometria da antena IFMA, dimensões em $\mathrm{mm}$.......................................

Figura 5.2 - Estrutura da IFMA simples representada da interface do FDTDStudio ...........38

Figura 5.3 - Impedância simulada da IFMA simples......................................................

Figura 5.4 - Perdas de retorno simuladas da IFMA simples ............................................39

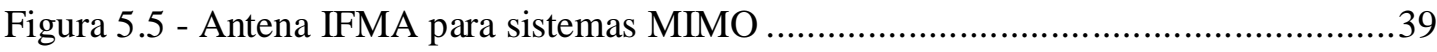

Figura 5.6 - Estrutura da IFMA MIMO representada da interface do FDTDStudio ...........40

Figura 5.7 - Impedância simulada da IFMA para sistemas MIMO .................................41

Figura 5.8 - Perdas de retorno simuladas da IFMA para sistemas MIMO .......................41

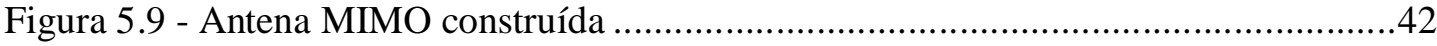

Figura 5.10 - Agilent RF NETWORK ANALYZER 8714ES ......................................42

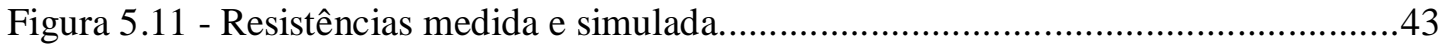

Figura 5.12 - Reatâncias medida e simulada ..................................................................44

Figura 5.13 - Perdas de Retorno medida e simulada ........................................................44 


\section{LISTA DE SIGLAS}

3GPP

ANATEL

AWGN

BER

CSI

HP

IFMA

LFMA

LOS

LTSD

MIMO

MISO

PIFA

SIMO

SISO

SLL

SMP

SNR

SVD
Third Generation Partnership Project

Agência Nacional de Telecomunicações

Additive White Gaussian Noise

Bit State Error

Channel State Information

Half Power beamwidth

I-Folded Monopole Antenna

L-Folded Monopole Antenna

Line-of-Sight

Laboratório de Tratamento de Superfícies e Dispositivos

Multiple Input Multiple Output

Multiple Input Single Output

Planar Inverse F-Antennas

Single Input Multiple Output

Single Input Single Output

Side Lobe Level

Serviço Móvel Pessoal

Signal-Noise Rate

Singular Value Decomposition 


\section{INTRODUÇÃO}

A busca por meios práticos e eficientes de comunicação que permitam aos usuários obter a informação desejada no instante e local em que se encontram é crescente na atualidade.

Um dos mais populares meios de comunicação, o serviço de telefonia celular apresenta números que refletem bem esse momento. Segundo dados da Agência Nacional de Telecomunicações (ANATEL), existem mais de 168 milhões de acessos do Serviço Móvel Pessoal (SMP) no Brasil, o que corresponde a aproximadamente 87,6\% da população nacional. Ainda de acordo com a ANATEL, cidades como São Paulo e Brasília possuem teledensidade maior que um, ou seja, existe mais de um acesso por pessoa [1].

Tais números se justificam pela evolução da indústria de telefonia móvel, que além de oferecer aparelhos mais modernos e integrados, passou a oferecer serviços diversos, como vídeo conferências e acesso à internet.

Com uma quantidade crescente de usuários e disponibilidade de diferentes serviços, surgiu a necessidade de buscar meios que otimizassem a utilização do espectro eletromagnético, uma vez que este é um recurso escasso e compartilhado com outras tecnologias diferentes e potencialmente interferentes. Pesquisas envolvendo todos os campos da transmissão e da recepção são desenvolvidas ao redor do globo, visando permitir que cada vez mais usuários possam experimentar uma gama maior de serviços com qualidade crescente.

Deste cenário evolutivo surgiu o 3GPP, formado em 1998 por grupos padronizadores de diferentes regiões do planeta, com o objetivo de alinhar as pesquisas na área, padronizando e acelerando o processo evolutivo do sistema [2]. Entre as propostas do grupo, está o uso da tecnologia MIMO (Multiple Input Multiple Output - Múltiplas Entradas Múltiplas Saídas) em sistemas celulares, por meio do qual diversas antenas dispostas na unidade móvel e na estação rádio base poderiam proporcionar maior capacidade e confiabilidade ao sistema, sem que para isso fosse necessária maior alocação de banda. 
A tecnologia multi-antena mostra-se uma importante aliada na busca pela utilização mais eficiente do espectro eletromagnético. Cada vez mais inserida no campo das telecomunicações, as transmissões MIMO proporcionam maior capacidade ao sistema, sem grandes alterações em quesitos como banda e potência transmitida. Entretanto, com a introdução da nova tecnologia, tanto a parte computacional como a parte física da transmissão precisou ser aperfeiçoada. Enquanto sistemas mais robustos e versáteis tiveram que ser desenvolvidos para realizar o gerenciamento de dados cada vez maior nas extremidades dos enlaces, novas antenas foram implementadas com o objetivo de vencer os desafios de acoplamento mútuo e de limitação espacial.

Todavia, mesmo diante de um cenário evolutivo fomentado por grandes investimentos em desenvolvimento e pesquisa, a tecnologia MIMO ainda apresenta algumas lacunas no que diz respeito à forma ideal de transmissão do sistema.

Diante de uma evolução que aponta para a tecnologia MIMO como técnica de transmissão a ser difundida nas comunicações sem fio, inclusive a celular, foi realizado um estudo visando o entendimento geral de sistemas MIMO e de aspectos básicos de antenas para, a partir daí, promover simulações em busca de um modelo pequeno e eficiente de múltiplas antenas para dispositivos móveis celulares e sua posterior implementação.

No Capítulo 2 deste trabalho é realizado um estudo geral da tecnologia MIMO, buscando elucidar seu funcionamento e enumerando suas vantagens e limitações, bem como aspectos importantes como capacidade de um canal multi-antena.

O Capítulo 3 aborda aspectos básicos sobre antenas, descrevendo alguns dos parâmetros que devem ser analisados no projeto e na escolha de antenas.

O processo de validação do software utilizado, bem como a determinação da matriz de impedância de uma estrutura com múltiplas antenas através de simulação são descritos no Capítulo 4.

Os resultados de simulação e testes da estrutura construída são apresentados e analisados no Capítulo 5 e, por fim, o Capítulo 6 traz as conclusões obtidas e propostas para futuros estudos. 


\section{TECNOLOGIA MIMO}

\subsection{Introdução}

Com a crescente evolução dos sistemas de comunicação sem fio, cada vez mais serviços são oferecidos, o que torna necessária a busca por meios que otimizem os recursos existentes para aumentar a capacidade de transmissão do canal e melhorar sua qualidade.

Embora pareçam óbvias, soluções como aumento da potência do sinal transmitido ou da banda a ele alocada não resolvem o problema. Enquanto o aumento indefinido de potência geraria enormes gastos com equipamentos e causaria ruídos indesejáveis em canais adjacentes, o aumento da banda alocada é limitado pelo fato de o espectro eletromagnético ser finito e extremamente caro.

Desenvolvida pelos laboratórios Bell na década de 90, a tecnologia MIMO (Multiple Input - Multiple Output) consiste na utilização de mais de uma antena em cada uma das extremidades de um sistema de comunicação sem fio, ou seja, mais de um elemento transmissor e receptor. Tais sistemas tornaram-se objeto de muitas pesquisas, uma vez que se mostram uma alternativa interessante para os desafios de otimização do espectro eletromagnético através de técnicas como ganho de arranjo, diversidade espacial e multiplexação espacial.

\subsection{Sistemas MIMO}

Com a utilização de múltiplas antenas nas extremidades de um sistema de comunicação, cada par transmissor/receptor pode ser interpretado como um canal diferente. Neste caso, cada percurso entre uma antena transmissora e uma antena receptora seria considerado um canal SISO (Single Input - Single Output) e as técnicas mencionadas podem ser implementadas para otimizar o sistema de comunicação.

A Figura 2.1 ilustra um sistema MIMO $\operatorname{com} \mathrm{N}_{\mathrm{t}} \times \mathrm{N}_{\mathrm{r}}$ antenas transmissoras e receptoras, respectivamente, em que em que $x=\left[\begin{array}{lllll}x_{0} & x_{1} & x_{2} & \ldots & x_{\mathrm{Nt}}\end{array}\right]$ e $y=\left[\begin{array}{lllll}y_{0} & y_{1} & y_{2} & \ldots & y_{\mathrm{Nr}}\end{array}\right]$ são os vetores de símbolos transmitidos e recebidos em uma dada frequência, de modo que $x_{i}$ 
representa o símbolo enviado pela $i$-ésima antena transmissora e $y_{j}$ representa o símbolo recepcionado na $j$-ésima antena receptora.

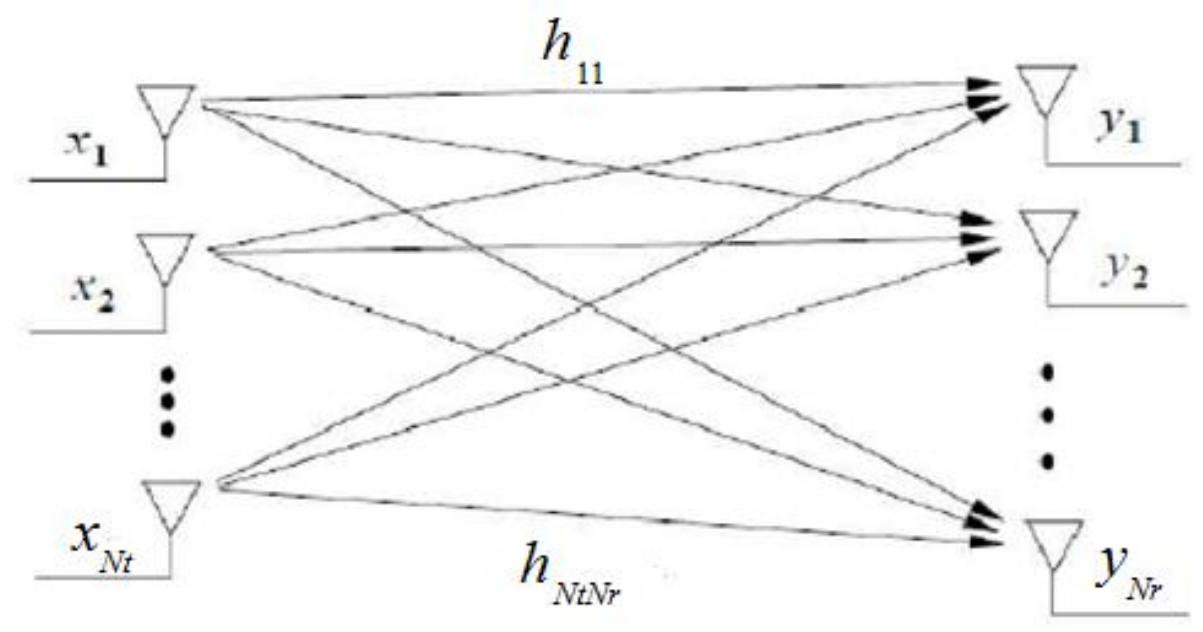

Figura 2.1 - Sistema MIMO simplificado

Nesse modelo, tem-se ainda a matriz $H$, de dimensões $\mathrm{N}_{\mathrm{t}} \times \mathrm{N}_{\mathrm{r}}$, em que cada elemento $h_{j, i}$ representa parâmetros do canal de transmissão formado entre cada par de antenas transmissora e receptora e $n$, que representa o ruído inserido no sinal. Assim, a relação entre o sinal transmitido e o sinal recebido será dada pela equação (2.1).

$$
y=H x+n
$$

Situação análoga é observada em sistemas SIMO (Single Input-Multiple Output) e sistemas MISO (Multiple Input - Single Output), possibilitando a utilização de ganho de arranjo e diversidade espacial para a otimização de tais sistemas.

Para maior eficiência de sistemas com múltiplas antenas, é necessário que os canais entre cada par transmissor/receptor estejam descorrelacionados, isto é, os sinais transmitidos em cada um desses canais devem experimentar diferentes situações de multipercurso e desvanecimento, sendo afetados de maneiras distintas pelo meio em que estão se propagando. Ambientes altamente dispersivos, como centros urbanos onde o sinal passa por diversos fenômenos de propagação, Figura 2.2, tornam mais viável a implementação de sistemas que possuam canais descorrelacionados. 


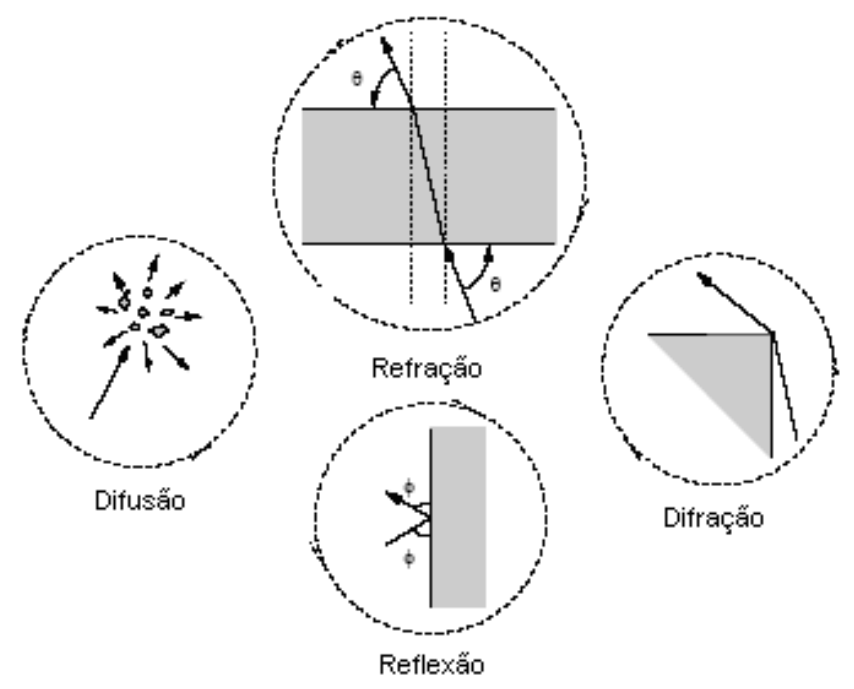

Figura 2.2 - Fenômenos de propagação

\subsection{Vantagens do Sistema MIMO}

\subsubsection{Ganho de Arranjo}

O ganho de arranjo é a técnica que possibilita o aumento da SNR (Signal-Noise Ratio - relação sinal ruído) no receptor através da combinação coerente da energia percebida em todas as antenas receptoras do sistema.

Mesmo na situação de propagação com linha de visada (LOS - line-of-sight) na qual existe a possibilidade de os canais serem completamente correlacionados, o incremento na relação sinal ruído média no receptor será linear e proporcional ao número de antenas receptoras.

Em sistemas como o ilustrado na Figura 2.1, o ganho de arranjo é definido como sendo igual ao número de antenas receptoras do sistema, como mostrado a seguir. Considerando um sistema 1 x $\mathrm{N}_{\mathrm{r}}$, cada receptor receberá um sinal dado por:

$$
y_{i}=h_{i} x_{i}+n_{i}=h x+n_{i}=y
$$


em que $h_{i}=h$ representa o parâmetro do canal entre transmissor e receptor, $x_{i}=x$ corresponde ao sinal enviado e $y_{i}=y$ corresponde ao sinal recebido, assumindo que todos os canais estejam perfeitamente correlacionados. Então, para uma transmissão com energia unitária, ou seja, esperança dos sinais transmitidos em cada canal $E|x|^{2}=1$, a relação sinal ruído recebida por cada antena será dada por:

$$
S N R=\frac{|h|^{2}}{\sigma^{2}}
$$

sendo $\sigma^{2}$ a potência do ruído. Assim, o sinal resultante recebido por todas as $\mathrm{N}_{\mathrm{r}}$ antenas receptoras será:

$$
y=\sum_{i=1}^{N_{r}} y_{i}=N_{r} h x+\sum_{i=1}^{N_{r}} n_{i}
$$

A relação sinal ruído resultante do arranjo de antenas, considerando que apenas os ruídos de cada ramo não estão correlacionados, será dada pela relação (2.5), comprovando que a SNR no receptor será incrementada linearmente com o número de antenas receptoras do sistema.

$$
S N R_{\Sigma}=\frac{\left|N_{r} h\right|^{2}}{N_{r} \sigma^{2}}=\frac{N_{r}|h|^{2}}{\sigma^{2}}
$$

\subsubsection{Diversidade Espacial}

Na técnica de diversidade a informação é transmitida em realizações distintas do canal, de forma a diminuir a probabilidade de erros na recuperação da mensagem. Como a probabilidade de um sinal chegar abaixo do limiar necessário para a sua recuperação é dada por $p_{e}$, a probabilidade de $\mathrm{N}$ sinais independentes chegarem abaixo desse limiar será de $p_{e}{ }^{N}$, aumentando consideravelmente a confiabilidade do sistema. Pode-se separar as técnicas de diversidade utilizadas em sistemas sem fio em três grupos: temporal, em frequência e espacial.

Diversidade Temporal: a mesma informação é enviada do transmissor ao receptor em intervalos de tempo diferentes e maiores que o intervalo de coerência do canal, provocando desvanecimentos independentes entre as palavras-código. Desta maneira, 
blocos de palavras que não foram recuperados satisfatoriamente podem ser recuperados através da transmissão em outro instante que experimentou condições mais favoráveis do canal. Para o caso de canais com intervalo de coerência muito grande, tal técnica tem como grande desvantagem o atraso injetado no sistema.

Diversidade em Frequência: opera de maneira análoga à diversidade temporal, fazendo com que a mesma palavra código experimente diferentes faixas de frequência de maneira a possibilitar desvanecimentos independentes, de acordo com a coerência do canal à frequência. Torna-se pouco interessante quando a banda de coerência do canal tem a largura similar à largura de banda da informação transmitida.

Diversidade Espacial: técnica por meio da qual a mesma informação é enviada por diferentes antenas, conforme Figura 2.3. Para o sucesso dessa técnica, é importante que os enlaces formados por diferentes pares de antenas transmissora/receptora apresentem baixa correlação, possibilitando que o código enviado através desses enlaces experimente diferentes desvanecimentos e a relação sinal ruído no receptor seja maior. O aumento de custo computacional, que provoca maior consumo de potência no sistema receptor; e a distância entre as antenas - cujo desempenho ideal ocorre quando estão separadas por uma distância de aproximadamente $38 \%$ do comprimento de onda - são obstáculos a serem superados, principalmente em se tratando de sistemas móveis e portáteis como o celular $[3]$.

O ganho resultante da técnica de diversidades espacial será definido pelo número de enlaces suficientemente descorrelacionados, que idealmente é dado pelo produto entre o número de antenas transmissoras e receptoras.

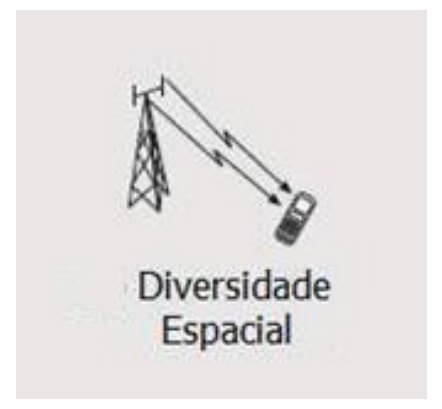

Figura 2.3 - Exemplo de diversidade espacial 
O Beamforming também permite explorar a diversidade espacial. Por meio de processamento de sinal, a direção e/ou o ângulo de chegada do feixe do sinal são ajustados, a fim de otimizar a energia utilizada ao transmitir de forma mais diretiva, conforme ilustrado na Figura 2.4. Desta maneira, evita-se que feixes com diferentes informações e destinos se sobreponham, diminuindo a interferência mútua entre eles.

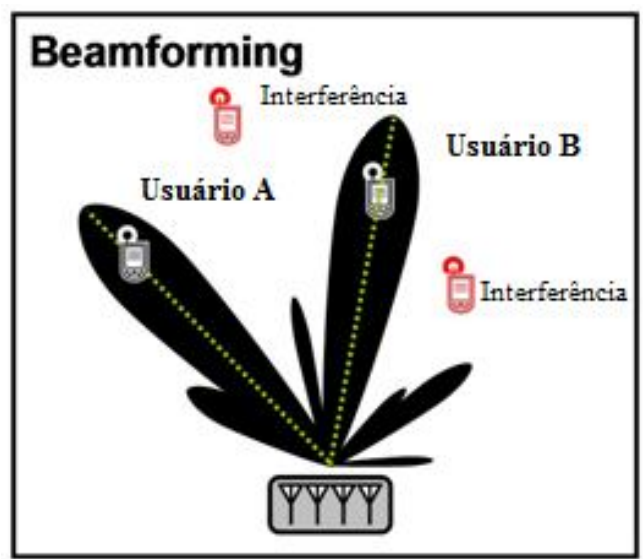

Figura 2.4 - Formação de feixe (beamforming) do sinal transmitido

As técnicas de diversidade podem ser usadas em conjunto, em uma tentativa de aumentar ainda mais a confiabilidade do canal. Em contrapartida, o acúmulo dessas técnicas proporcionará um sistema com grande complexidade operacional e taxas de transmissão abaixo das atingidas por sistemas que utilizem apenas uma forma de diversidade.

\subsubsection{Multiplexação Espacial}

Enquanto as técnicas mencionadas anteriormente visam o aumento de confiabilidade do sistema por meio da implementação de canais com maior SNR entregue ao receptor e menor BER (Bit Error Rate - taxa de erro de bits), a técnica da multiplexação espacial busca o aumento da taxa de transmissão de determinado sistema.

Esta técnica baseia-se na existência de canais paralelos e independentes formados entre as antenas transmissoras e receptoras, através dos quais é possível reutilizar os 
recursos do sistema de forma a viabilizar a transmissão de informações distintas no mesmo instante de tempo e na mesma faixa de frequência.

A multiplexação espacial pode ser dividida basicamente em dois tipos: Multiplexação multi-usuário, na qual o fluxo de dados transmitidos por diferentes antenas atingem diferentes usuários, Figura 2.5(a); e multiplexação usuário-único, na qual as diferentes antenas transmissoras fornecem diferentes informações ou serviços a um mesmo usuário, Figura 2.5(b).

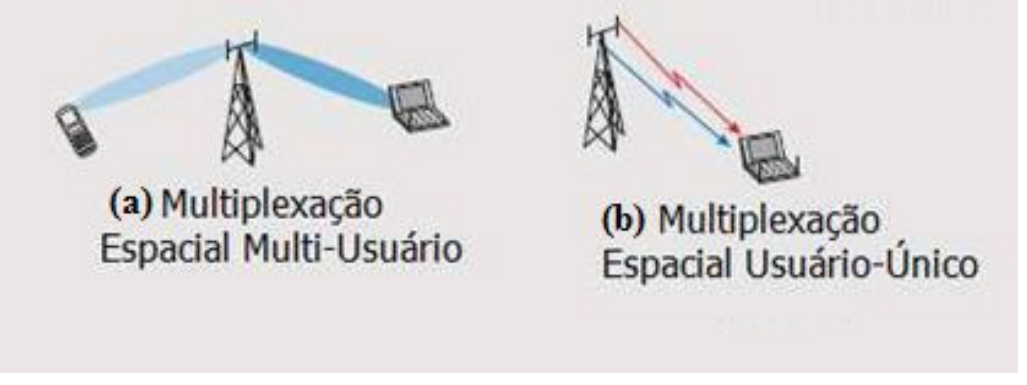

Figura 2.5 - Técnicas de transmissão em sistemas MIMO

\subsection{Decomposição em Paralelo do Canal MIMO}

A técnica da multiplexação espacial está intimamente ligada à decomposição em paralelo de sistemas MIMO. Isso porque ela baseia-se na possibilidade de formação de canais paralelos que permitam a transmissão de fluxo de dados independentes em cada um desses canais. $\mathrm{O}$ aumento da taxa de transmissão que se pode atingir com esses canais paralelos é chamando ganho de multiplexação, determinado pelo número de canais formados.

De acordo com a teoria matricial, para quaisquer $h_{j i}$, a matriz $H$, referente às condições do canal do sistema ilustrado pela Figura 2.1, pode ser decomposta em valores singulares (SVD - Singular Value Decomposition):

$$
H=U \sum V^{H}
$$

em que $U$ e $V$ são matrizes unitárias e têm dimensões $\mathrm{N}_{\mathrm{t}} \times \mathrm{N}_{\mathrm{t}}$ e $\mathrm{N}_{\mathrm{r}} \times \mathrm{N}_{\mathrm{r}}$, respectivamente, e $\sum$ é uma matriz com dimensões $\mathrm{N}_{\mathrm{r}} \times \mathrm{N}_{\mathrm{t}}$ com os elementos dados por: 


$$
\Sigma_{\mathrm{ij}}= \begin{cases}B_{i}, & i=j \\ 0, & i \neq j\end{cases}
$$

sendo $B_{i}$ o $i$-ésimo valor singular de $H$, ordenado de forma decrescente.

Se o canal possuir ganhos $h_{j i}$ completamente descorrelacionados, uma situação ideal e mais perto de ser atingida em grandes centros urbanos, o ganho de multiplexação máximo do sistema, igual a min $\left(N_{t}, N_{r}\right)$, será alcançado. Em contrapartida, nos casos em que os ganhos $h_{j i}$ estão altamente correlacionados, como nos sistemas LOS, o rank de $H$ e o ganho de multiplexação serão iguais à unidade, significando que não há vantagem na transmissão e recepção com múltiplas antenas. Portanto, o ganho de multiplexação é determinado pelo rank de $H$ e, consequentemente, pelo número de canais paralelos independentes para fluxo de dados em que o sistema MIMO poderá ser decomposto.

A decomposição em canais paralelos será realizada a partir de uma pré-codificação no transmissor e uma pós-codificação do sinal no receptor. Para isso, é necessário que haja conhecimento do canal nas duas extremidades do sistema, possibilitando que, por meio de processamento do sinal a ser enviado, o vetor do sinal transmitido $\dot{x}$ passe por transformações lineares e resulte em um sinal codificado $x=V^{H} \dot{x}$ na entrada das antenas transmissoras. $\mathrm{O}$ mesmo acontece na saída das antenas receptoras, em que o sinal y na saída do canal será processado e resultará em $\dot{y}=U^{H} y$, conforme ilustrado na Figura 2.6

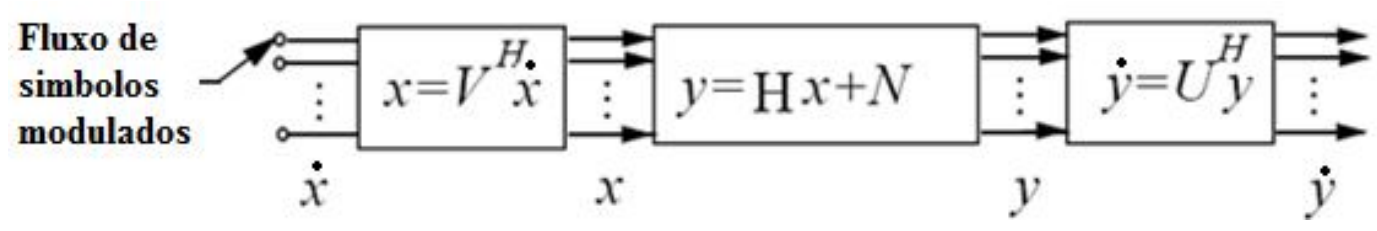

Figura 2.6 - Processamento dos dados nos sistemas transmissor e receptor

Com a possibilidade de pré e pós-codificação do fluxo de dados, o canal MIMO pode ser tratado como $\mathrm{R}_{\mathrm{H}}$ canais SISO independentes com $\dot{x}$ e $\dot{y}$ como entrada e saída, respectivamente, em que $\mathrm{R}_{\mathrm{H}}$ é o rank de $H$. 
Assim, como resultado da decomposição em valores singulares de $H$ e das codificações impostas aos sinais transmitidos e recebidos em um sistema como o da equação (2.1), tem-se:

$$
\begin{aligned}
\dot{y} & =U^{H}(H x+n)= \\
& =U^{H}(U \Sigma V x+n)= \\
& =U^{H}\left(U \Sigma V V^{H} \dot{x}+n\right)= \\
& =U^{H} U \Sigma V V^{H} \dot{x}+U^{H} n= \\
& =\Sigma \dot{x}+\dot{n}
\end{aligned}
$$

Desta maneira, o sistema será representado por $\mathrm{R}_{\mathrm{H}}$ canais paralelos e independentes, cada um com entrada $\dot{x}_{i}$, saída $\dot{y}_{i}$, ruído $\dot{n}_{i}$ e ganho $\sigma_{i}$ correspondentes, como ilustrado na Figura 2.7. Com os $R_{H}$ canais paralelos, o canal poderá transmitir $R_{H}$ vezes a capacidade de um sistema com apenas um transmissor e receptor, caracterizando assim a vantagem de se usar a multiplexação por múltiplas antenas.

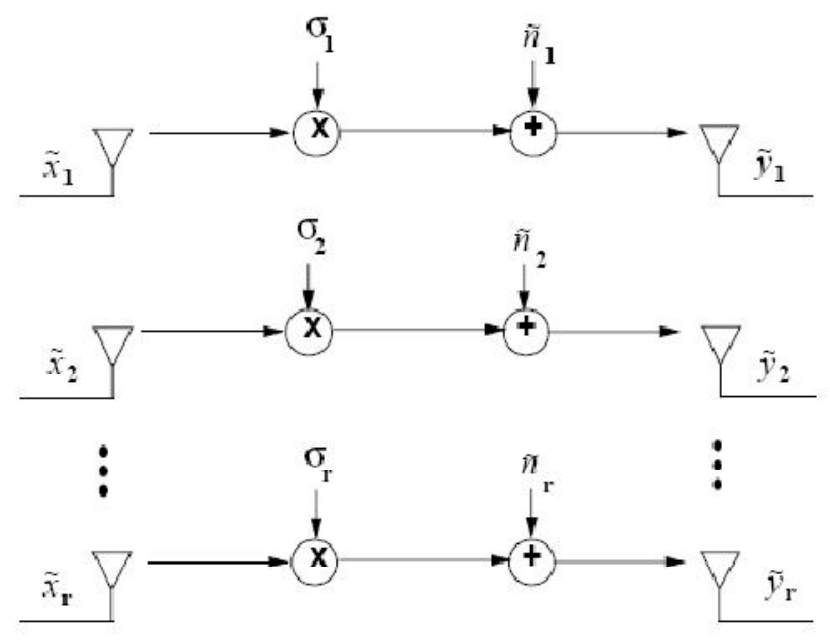

Figura 2.7 - Resultado da decomposição em paralelo de um canal MIMO

\subsubsection{Compromisso entre Multiplexação e Diversidade}

Como visto anteriormente, as múltiplas antenas de um sistema MIMO podem ser utilizadas para gerar ganho de multiplexação, aumentando a capacidade do sistema, e para gerar ganho de diversidade, tornando o sistema mais confiável e robusto a 
desvanecimentos. Entretanto, não é possível conseguir, simultaneamente, a máxima eficiência do sistema em ambos os aspectos, existindo um compromisso a ser observado entre diversidade e multiplexação, ou seja, entre capacidade e confiabilidade.

Muitos esforços no sentido de combinar diversidade e multiplicação têm sido realizados e, embora não seja possível obter simultaneamente o máximo de cada uma destas técnicas de otimização do canal, já existem técnicas de codificação que permitem um aproveitamento bastante interessante do uso conjunto delas.

O compromisso entre a ordem de diversidade e o grau de multiplexação de dados em um sistema com $M_{T}$ transmissores e $M_{R}$ receptores é dado pela equação [4].

$$
g_{d o p t}\left(g_{r}\right)=\left(M_{t}-g_{r}\right)\left(M_{r}-g_{r}\right)
$$

em que $g_{d}$ representa a ordem de diversidade e $g_{r}$, o ganho de multiplexação. A Figura 2.8 ilustra esse compromisso na situação em que todos os canais estão descorrelacionados e demonstra que, quando é necessária maior confiabilidade do sistema, como no envio de dados em transações bancárias, a ordem de diversidade será priorizada em detrimento do ganho de multiplexação. Já em sistemas nos quais a confiabilidade não é tão importante, como em wlans domésticas, pode-se abrir mão da ordem de diversidade a fim de um ganho de multiplexação maior, aumentando a capacidade do canal.

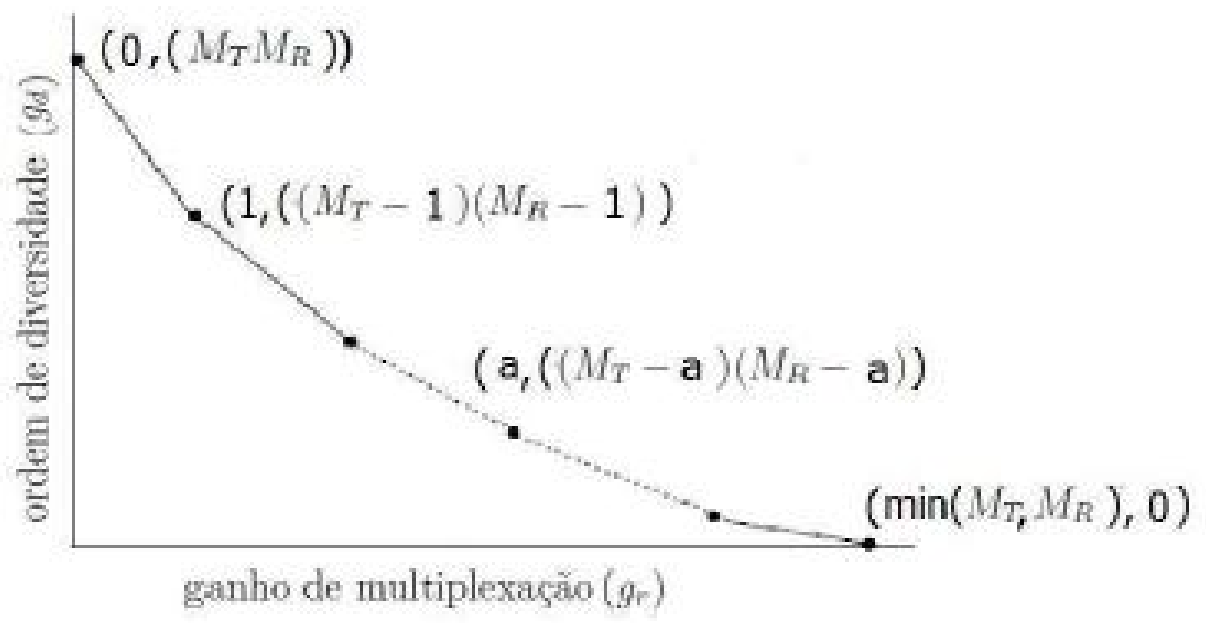

Figura 2.8 - Compromisso entre multiplexação e diversidade 


\subsection{Capacidade do Canal MIMO}

Entende-se por capacidade a máxima taxa de dados que pode ser transmitida por um canal em determinado intervalo de tempo, respeitando uma BER especificada. A capacidade de um canal depende do conhecimento de transmissores e/ou receptores acerca das condições do canal de transmissão, bem como das condições do canal de comunicação utilizado e da disponibilidade que se deseja do canal.

Nesta sessão, consideram-se canais estáticos e com CSI (Channel State Information - Informação do Estado do Canal) no transmissor e no receptor. A hipótese de conhecimento do canal no transmissor permite desconsiderar a capacidade de outage (aquela que leva em consideração a disponibilidade do canal, ou seja, a probabilidade da mensagem enviada não ser recebida de maneira correta pelos receptores).

A capacidade dos canais AWGN (Additive White Gaussian Noise - Ruído Gaussiano Branco Adicionado) é dada pelo teorema de Shannon:

$$
C=B \log _{2}(1+S N R)
$$

em que $S N R$ representa a relação sinal ruído no receptor e $\mathrm{B}$, a banda alocada pelo sinal. Pelo teorema de Shannon, qualquer código transmitido a uma taxa $R>C$ terá a probabilidade de erro afastando-se cada vez mais de zero, de acordo com o crescimento de R. Tal teorema é provado através do conceito de informação mútua entre a entrada e a saída do sistema. Para canais invariantes no tempo, com entrada e saída aleatórias $x$ e $y$, a informação mútua será definida por:

$$
I(X ; Y)=\sum_{x \in X, y \in Y} p(x, y) \log \left(\frac{p(x, y)}{p(x) p(y)}\right)
$$

sendo o somatório caracterizado por pares de entrada e saídas $x \in X$ e $y \in Y$, em que $X$ e $Y$ são os possíveis alfabetos de entrada e saída, respectivamente. Maximizando-se a equação (2.11), tem-se a capacidade de um canal AWGN.

Como demonstrado na sessão 2.3, sistemas MIMO nos quais transmissores e receptores possuem informações sobre as condições do canal podem ser decompostos em canais paralelos e, consequentemente, terão sua capacidade determinada pela soma das capacidades individuais de cada canal paralelo. Assim, a capacidade resultante será: 


$$
C=\max _{\rho i: \sum_{i} \rho i \geq \rho} \sum_{i} B \log _{2}\left(1+\sigma_{i}^{2} \rho_{i}\right)
$$

em que pode-se substituir $\rho=\mathrm{P} / \sigma_{\mathrm{n}}^{2}$, possibilitando definir a capacidade em termos da potência alocada em cada um dos $i$ canais formados:

$$
C=\max _{\rho i: \sum_{i} \rho i \geq \rho} \sum_{i} B \log _{2}\left(1+\frac{\sigma_{i}^{2} P_{i}}{\sigma_{n}^{2}}\right)=\max _{\rho i: \sum_{i} \rho i \geq \rho} \sum_{i} B \log _{2}\left(1+\frac{P_{i} \gamma_{i}}{P}\right)
$$

considerando $\rho_{\mathrm{i}}=\mathrm{P}_{\mathrm{i}} / \sigma_{\mathrm{n}}^{2}$ e $S N R=\sigma_{\mathrm{i}}^{2} \mathrm{P} / \sigma_{n}^{2}$ como sendo a relação sinal-ruído do $i$ ésimo canal com potêncial total.

A expressão (2.13) é a mesma para os casos com desvanecimento sensível ou não à frequência e, no caso da distribuição de water-filling - aquela tida como ideal, em que a potência é maior para canais com condições mais favoráveis - a capacidade de canais MIMO será dada por [4]

$$
C=\sum_{i: \gamma_{\mathrm{i}} \gamma_{0}} B \log _{2}\left(\gamma_{\mathrm{i}} / \gamma_{0}\right)
$$

sendo

$$
\frac{P_{i}}{P}=\left\{\begin{array}{cc}
\frac{1}{\gamma_{0}}-\frac{1}{\gamma_{\mathrm{i}}} & \gamma_{\mathrm{i} \geq \gamma_{0}} \\
0 & \gamma_{\mathrm{i} \geq} \gamma_{0}
\end{array}\right.
$$

\subsection{Limitações do Sistema MIMO}

Nas sessões anteriores, o sistema MIMO foi apontado como uma importante alternativa para mitigar as limitações de qualidade e capacidade de sistemas de comunicação sem fio. Entretanto, as análises feitas ao longo deste capítulo levaram em consideração apenas situações ideais, que dificilmente são implementadas em sistemas reais.

A decomposição em paralelo de canais MIMO - vista no item 2.3 - é uma solução interessante em termos de capacidade do canal, pois a máxima taxa de transmissão possível no sistema é analisada como sendo o somatório da capacidade de diversos canais 
independentes. Porém, para que essa situação seja realmente percebida, é necessário que as antenas do sistema estejam completamente descorrelacionadas, cenário dificilmente realizável, principalmente em se tratando de dispositivos móveis e compactos, como os celulares, em que não há espaço físico para que as antenas estejam suficientemente separadas.

A falta de espaço em dispositivos compactos, além de possivelmente provocar uma alta correlação entre as antenas, também provoca a presença da indutância mútua entre os dispositivos - fator que merece estudos cuidadosos a fim de não permitir que as múltiplas antenas se interfiram destrutivamente - e a existência de interferência de canal adjacente relevante.

Ainda na técnica de decomposição do sistema MIMO em canais paralelos, é necessário que transmissores e receptores possuam informações sobre o canal para que possa haver codificação e decodificação do sistema no transmissor e receptor, respectivamente. A CSI tem sua qualidade atrelada à variação do canal no tempo. Em canais com menor variação temporal, a estimação realizada representará com maior confiabilidade as condições do canal, em contrapartida, será menos condizente com o estado momentâneo do canal em sistemas suscetíveis a variações mais frequentes, uma vez que existe um tempo de latência entre a detecção do estado do canal e a efetiva utilização da informação para processamento do sinal.

Desconsiderar a banda alocada para a criação de um canal de feedback, por meio do qual o receptor envia bits de informação do canal para o transmissor, e assumir o ruído como baixo, gaussiano e descorrelacionado com a transmissão também são técnicas utilizadas para, teoricamente, simplificar o sistema e melhorar seu desempenho, mas representariam grandes obstáculos na implementação real de um sistema MIMO [5]. 


\section{ANTENAS}

\subsection{Introdução}

Como visto no capítulo anterior, sistemas MIMO são baseados em arranjos de múltiplas antenas na transmissão e na recepção do enlace. De acordo com a definição do IEEE, antenas são "ferramentas para radiação ou recepção de ondas de rádio" [6], ou seja, antenas funcionam, em um sistema de comunicação, como a interface entre o espaço livre e a linha de transmissão ou guia de onda. O mecanismo de radiação de uma antena é demonstrado na Figura 3.1.

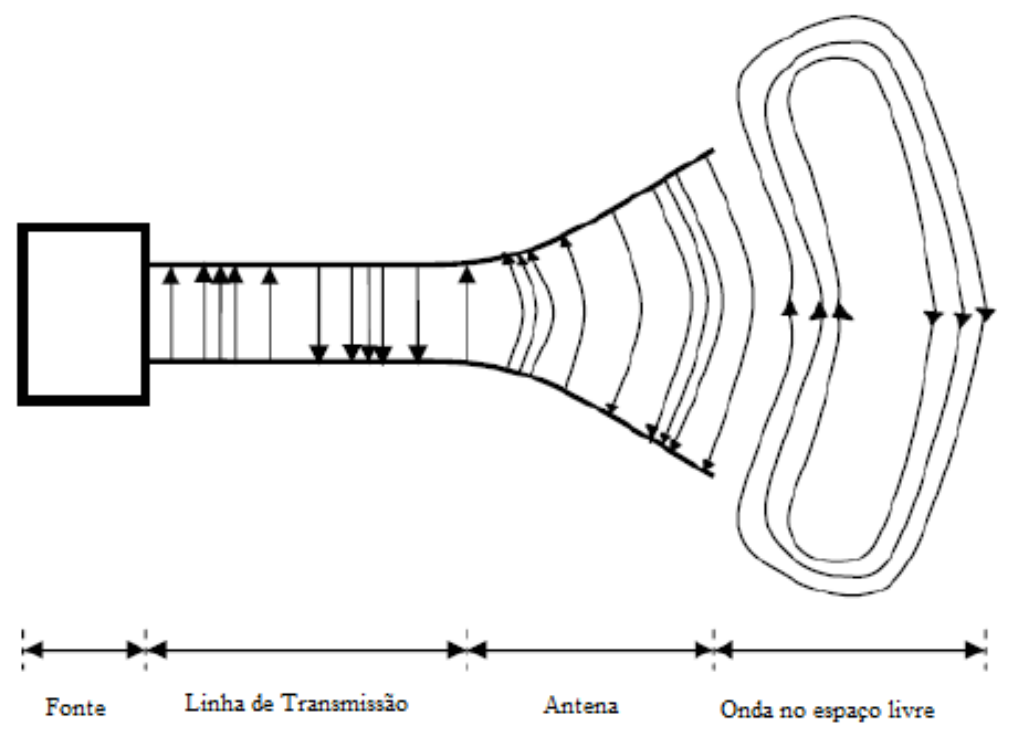

Figura 3.1 - Mecanismo de radiação de uma antena

$\mathrm{Na}$ transmissão, as antenas são usadas com o intuito de dar continuidade às ondas geradas por uma fonte, exercendo o papel de elemento de transição entre a linha de transmissão e o espaço livre. Na recepção, as antenas capturam as ondas propagantes no ar que, por meio da linha de transmissão, são levadas ao receptor.

A história das antenas de rádio teve início por volta de 1887. Ao longo desses mais de cem anos, alguns episódios importantes tiveram destaque, como a primeira transmissão de sinal entre localidades separadas pelo Oceano Atlântico, em 1901, quando Marconi 
utilizou 50 fios de cobre como antenas para transmitir parte do Código Morse da Inglaterra até o Canadá.

Grande parte do desenvolvimento da teoria de antenas se deu durante a Segunda Guerra Mundial, com a introdução de novos tipos de antenas de micro-ondas. Quando S. K. Schelkunoff, dos Laboratórios Bell, formulou matematicamente o mecanismo de radiação de várias antenas, ele aproximou a teoria da prática e melhorou o entendimento, à época, desses mecanismos [7].

Atualmente, em função dos avanços na área de processamento de dados que permitem simulações cada vez mais fiéis à realidade, os estudos na área de antenas evoluem rapidamente. Antenas de diferentes tipos e com diferentes finalidades - que vão desde a transmissão de rádio e televisão até a exploração do espaço - são desenvolvidas e aperfeiçoadas, possibilitando que informação seja transmitida em situações cada vez mais adversas com uma qualidade crescente.

\subsection{Conceitos Básicos}

Para continuidade dos estudos sobre antenas, é necessário que se definam alguns aspectos básicos, como as regiões de ação das antenas e o significado de cada um dos indicadores de desempenho que serão analisados.

\subsubsection{Regiões de Ação das Antenas}

Os parâmetros de radiação associados a uma antena estão intimamente ligados à distância entre as extremidades da transmissão. Pode-se dividir, em função da distância entre transmissor e receptor, a área de ação da antena em três diferentes regiões, nas quais as intensidades de energia radiada e energia reativa serão diferentes. Tomando-se como referência a Figura 3.2, em que $R_{1}$ e $R_{2}$ são as distâncias para o transmissor, $D$ é a maior dimensão da antena e $\lambda$ é o comprimento de onda, tem-se as regiões apresentadas a seguir.

Região Reativa de Campo Próximo: Nesta região, delimitada por um raio $R_{1}=$ $0,62 \sqrt{D^{3} / \lambda}$, a energia é apenas armazenada, dominando o campo reativo.

Região Radiante de Campo Próximo: Nesta região, também conhecida como região de Fresnel, os campos reativos são consideravelmente menores se comparados com a 
região anterior e já existe domínio dos campos radiantes. Nesta área, que tem como limites inferior e superior os raios $R_{1}=0,62 \sqrt{D^{3} / \lambda}$ e $R_{2}=2 D^{2} / \lambda$, respectivamente, a distribuição angular do campo varia em função da distância da antena.

Região de Campo Distante: Nesta região, existem apenas campos radiantes, sendo nula a influência de campos reativos. Delimitada inferiormente por $R_{2}$, não há variação angular do campo dependente da distância. Entretanto, a distância influencia na densidade de potência percebida, que varia com o inverso do quadrado da distância radial.

Em se tratando de sistemas de comunicação celular, a região a ser considerada nos estudos é a região de campo distante, uma vez que as células sempre possuem raio maior que $R_{2}$. Entretanto, na implementação de sistemas MIMO, é muito importante a análise da região reativa de campo próximo, uma vez que as relações entre as antenas, como o acoplamento indutivo, devem ser estudadas.

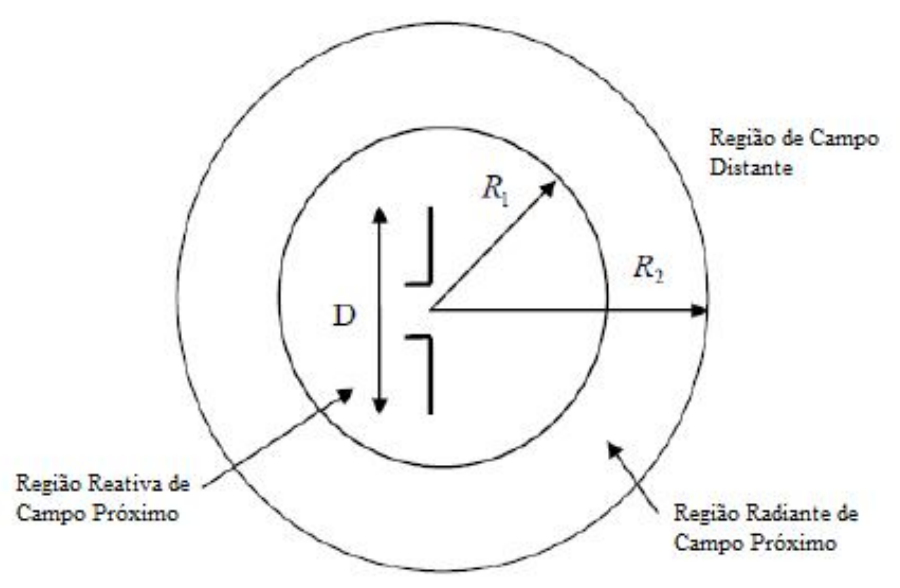

Figura 3.2 - Regiões de ação das antenas

\subsubsection{Parâmetros do Diagrama de Radiação}

Agora que a região de estudo já foi definida, pode-se abordar alguns parâmetros importantes no estudo de antenas. O diagrama de radiação é a representação gráfica das propriedades de radiação de uma antena em função de coordenadas espaciais. Nesse tipo de diagrama, determinada uma distância radial, é possível analisar a influência da antena para infinitos planos com a variação dos ângulos $\phi$ e $\theta$, considerando a representação espacial em coordenadas esférica, como na Figura 3.3. 


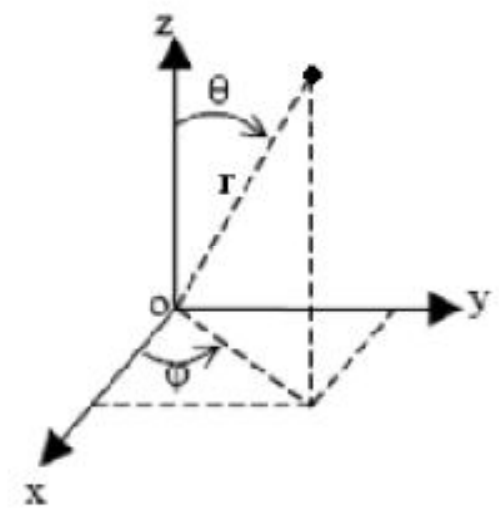

Figura 3.3 - Sistema de coordenadas esféricas

Em função da existência de infinitos planos para a elaboração do diagrama de radiação, foram definidos os planos $\mathrm{E}$ e $\mathrm{H}$ como sendo os mais importantes, a fim de facilitar os estudos. Para uma antena com polarização linear, o plano E é aquele que contém o vetor associado à direção de máxima radiação do campo elétrico enquanto o campo $\mathrm{H}$ é aquele que possui o vetor associado à direção de máxima radiação do campo magnético [7].

Existe ainda a possibilidade de se expressar a radiação da antena em três dimensões, bastando para isso a rotação em torno do eixo de simetria do plano E, conforme exemplo para dipolo ideal na Figura 3.4.
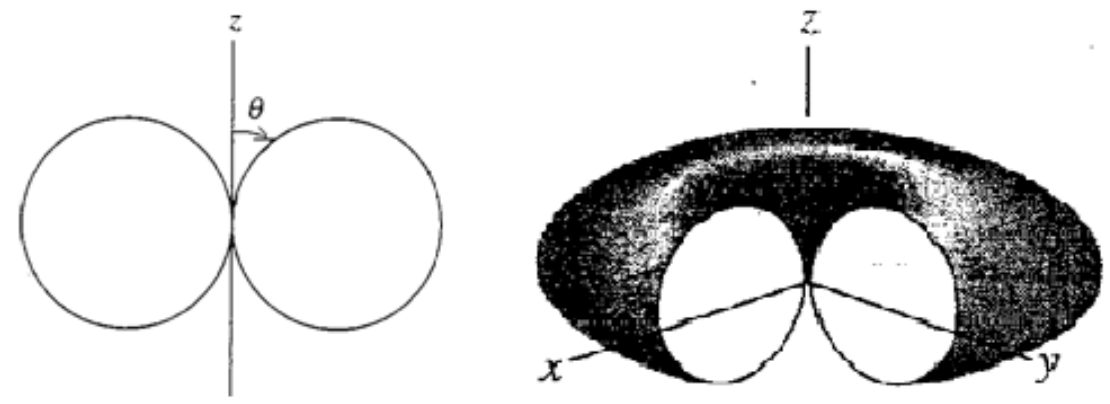

Figura 3.4 - Plano E do dipolo ideal e sua rotação em eixo de simetria

É necessário identificar os elementos de um diagrama de radiação e o que cada um deles significa. Os principais deles, representados na Figura 3.5, são: 
Lóbulo principal: também conhecido como lóbulo maior, este lóbulo representa a direção de máxima radiação. Em determinadas antenas, podem existir mais de um lóbulo principal.

Lóbulo menor (Side Lobe Level - SLL): é caracterizado por quaisquer lóbulos que não sejam os principais. Pode estar em posição adjacente ao lóbulo principal - lóbulo lateral - ou em posição oposta a ele - lóbulo traseiro. Em antenas que possuem mais de um lóbulo principal, os lóbulos menores podem ser denominados apenas como lóbulos laterais. Normalmente os lóbulos menores representam radiação emitida em direções indesejadas, o que deve ser minimizado. A relevância dos lóbulos menores é medida através da razão entre a sua intensidade de potência e a intensidade de potência do lóbulo principal. Lóbulos menores com valores inferiores a $-20 \mathrm{~dB}$ em relação ao lóbulo pricipal não são nocivos à maioria dos sistemas de telecomunicações [7].

Feixe de meia potência (Half-Power beamwidth - HP): considerando o lóbulo principal, o feixe de meia potência corresponde ao ângulo em que as laterais do lóbulo atingem a metade da máxima potência medida, ou seja, o ângulo formado pelos pontos em que o lóbulo está $3 \mathrm{~dB}$ abaixo de seu pico.

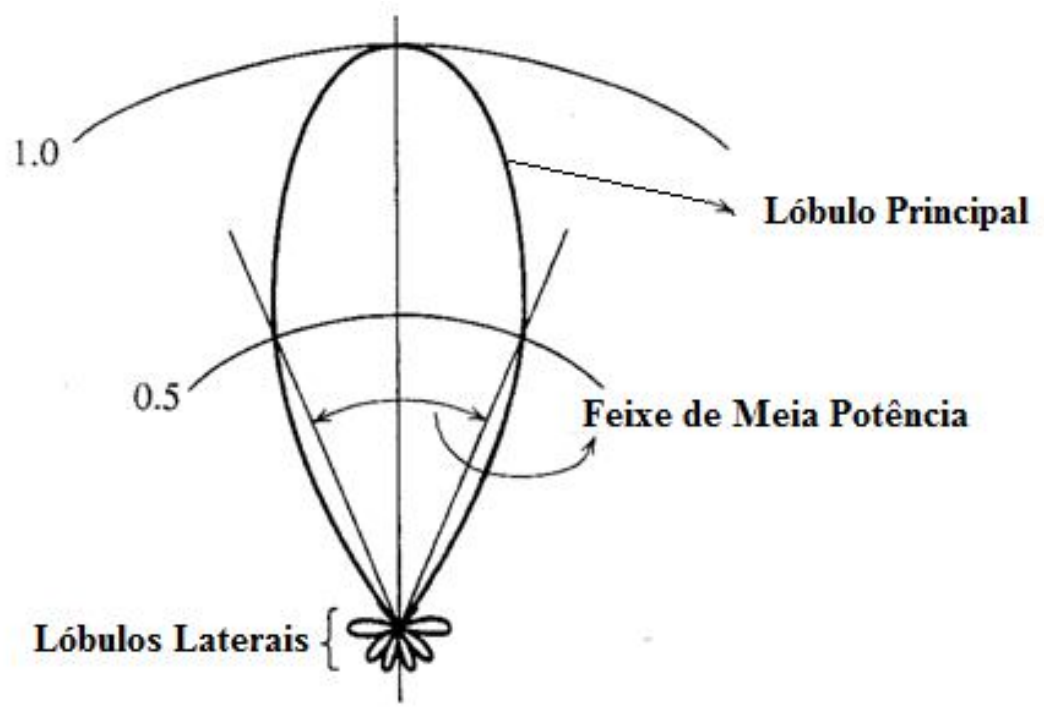

Figura 3.5 - Lóbulo principal, lóbulos laterais e feixe de meia potência 


\subsubsection{Diretividade e Ganho}

Diretividade é a razão entre a intensidade radiada pela antena estudada em certa direção e a intensidade radiada por uma antena de referência. A antena isotrópica é a mais comumente utilizada como referência, por ter uma distribuição angular de potência homogênea. Quando a direção da diretividade não está especificada, ela será calculada tomando como base a direção de máxima intensidade de radiação, como ilustrado na Figura 3.6.
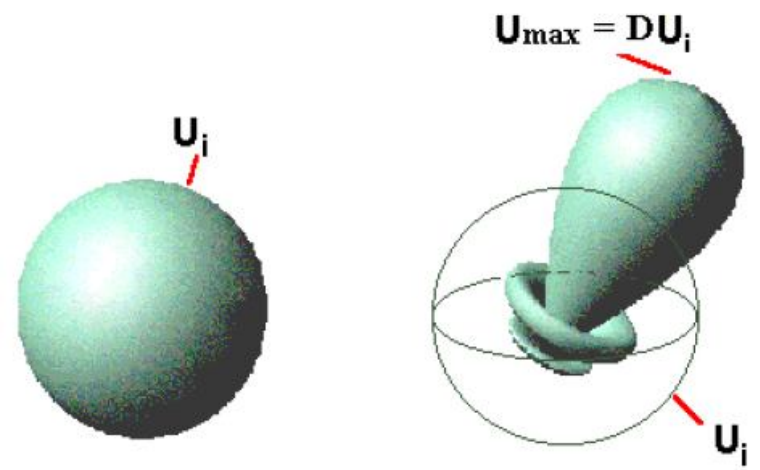

Figura 3.6 - Diretividade em relação à antena isotrópica

Ganho é uma medida que leva em consideração tanto a eficiência da antena quanto as suas capacidades direcionais. Assim, para casos de antena ideal (com eficiência de $100 \%$ ), ganho e diretividade são iguais, como pode ser observado na equação (3.1), em que é a eficiência da antena, $G(\theta, \phi)$ o ganho e $D(\theta, \phi)$ a diretividade, sendo os dois últimos funções da posição angular do ponto analisado.

$$
G(\theta, \phi)=e D(\theta, \phi)
$$

\subsubsection{Impedância de Entrada}

A impedância de entrada é definida como a impedância apresentada pela antena em seus terminais; ou, simplesmente, a razão entre a tensão e a corrente em seus terminais. Composta por uma parte resistiva e outra reativa, conforme equação (3.2), a impedância de 
entrada pode variar com a frequência de operação ou com a presença de indutância mútua causada por outras antenas ou elementos indutivos próximos ao objeto de estudo.

$$
Z_{A}=R_{A}+j X_{A}
$$

em que $Z_{A}$ é a impedância nos terminais da antena; $R_{A}$ é a resistência nos terminais da antena, associadas a perdas de radiação e ôhmicas; e $X_{A}$ é o elemento reativo de $Z_{A}$, responsável pela potência armazenada no campo próximo da antena.

Quando utilizada como elemento transmissor, a antena normalmente é alimentada pela fonte por intermédio de uma linha de transmissão ou guia de onda. Nestes casos, para que se consiga máxima transmissão de potência, é necessário que a impedância da linha de transmissão ou guia de onda seja igual ao conjugado da impedância da antena, conforme equação (3.3) [8]

$$
Z_{A}=Z_{L}^{*}
$$

\subsubsection{Largura de Banda}

A largura de banda é um parâmetro importante no estudo de antenas. Isso porque nenhuma antena é capaz de manter seu funcionamento em níveis satisfatórios em toda faixa do espectro. Assim, largura de banda é a faixa de frequências nas quais o desempenho da antena, com respeito a características como impedância de entrada, padrões de radiação e coeficiente de reflexão, mantém-se em níveis aceitáveis.

Portanto, para que o projeto de uma antena obtenha sucesso, um dos aspectos mais importantes é o conhecimento da faixa da frequência em que se deseja operar, pois uma mesma antena possui parâmetros intensamente distintos em faixas de operações diferentes.

\subsubsection{Tipos de Polarização}

A polarização de uma antena em certa direção é definida como a polarização da onda radiada quando a antena é excitada. Na prática, a polarização das ondas radiadas varia 
com a posição relativa ao centro da antena, mas, para fins de classificação, a polarização da antena será igual à polarização das ondas transmitidas quando na região de máximo ganho.

O percurso descrito pelo vetor de campo elétrico com a variação do tempo, considerando sua mudança de direção e de amplitude relativa, é o que caracteriza a polarização da onda. Classificada como linear, circular ou elíptica, Figura 3.7, o vetor de campo elétrico geralmente descreve a figura de uma elípse ao longo do tempo polarização elíptica -, sendo os casos linear e circular situações particulares, em que a elípse se transforma em uma linha reta ou um círculo, respectivamente.

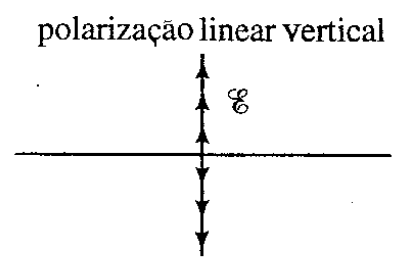

polarizaçăo circular horária

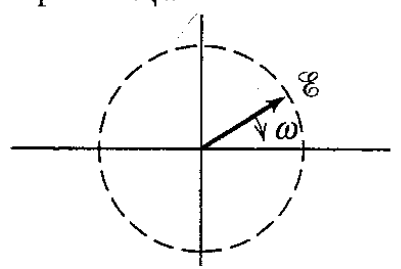

polarização elíptica horária

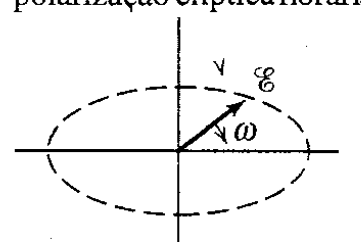

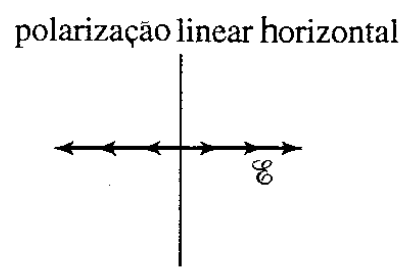

polarizaçăo circular anti-horária

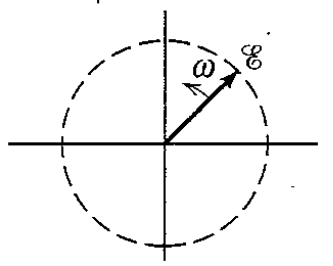

polarização elíptica anti-horária

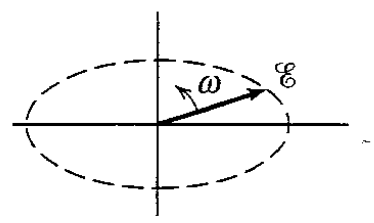

Figura 3.7 - Tipos de polarização

\subsection{Tipos de Antenas}

Existem diversos tipos de antenas, variando de acordo com forma, tamanho e material de que são feitas. Cada um dos tipos de antenas é mais adequado a determinado uso, possuindo melhor desempenho em um parâmetro em detrimento dos outros. Alguns dos tipos mais usuais de antenas serão resumidamente descritos nesta seção. 


\subsubsection{Antenas Lineares}

Construído através de fios ou hastes metálicas lineares esse é o tipo de antena mais antigo, simples, barato e com maior versatilidade. Por terem a freqüência de operação vinculada ao comprimento dos monopolos e dipolos que as representam, as antenas lineares têm aplicações diversas, como em telefonia móvel, carros, navios, prédios, entre outros. Alguns exemplos de antenas lineares estão ilustrados na Figura 3.8.
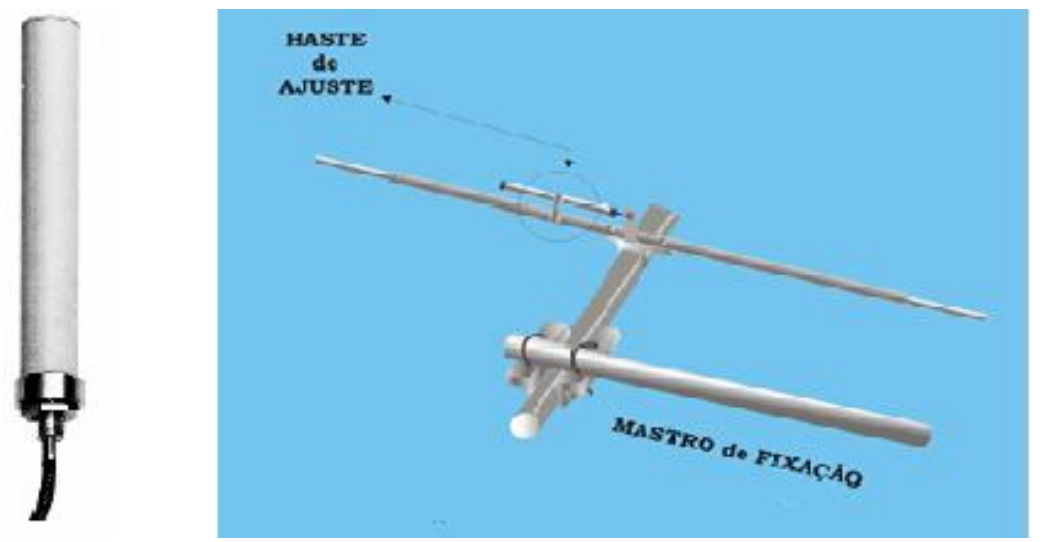

Figura 3.8 - Exemplos de antenas lineares

\subsubsection{Antenas em Loop}

Simples e versáteis como as antenas lineares, as antenas em loop podem tomar várias formas, como circular, elíptica, retangular, entre outras, bem como apresentar um ou mais loops. Antenas com pequeno perímetro ou circunferência apresentam baixa resistência de radiação, o que as torna mais viáveis na recepção do que na transmissão. Para aumentar a resistência de radiação desse tipo de antena, basta aumentar o perímetro ou circunferência do loop, aumentar o número de voltas ou mesmo inserir um núcleo de ferrite com grande permeabilidade com o intuito de aumentar a intensidade do campo magnético próximo à antena e tornará viável sua utilização em transmissões. Exemplos de antenas em loop podem ser vistos na Figura 3.9. 


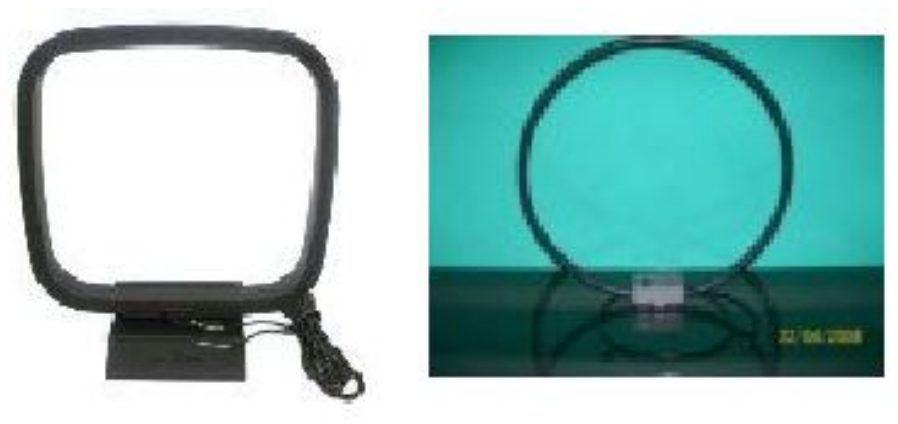

Figura 3.9 - Exemplos de antenas em loop

\subsubsection{Antenas de Abertura}

Mais sofisticadas e elaboradas que as antenas de fio metálico, as antenas de abertura são bastante diretivas e eficientes, além de possuírem alto ganho. São projetadas em forma de guia de ondas ou de corneta, cuja abertura pode ter formato circular, quadrado, retangular, elíptico ou de qualquer outra configuração que direcione as ondas em seu interior ao canal de transmissão. São utilizadas na transmissão de micro-ondas, o que torna seu uso comum nas comunicações via satélite, bem como em aviões, devido à possibilidade de proteção contra fenômenos naturais e fácil instalação na superfície da aeronave, sem que seu desempenho seja comprometido pelas altas velocidades atingidas. Para aumentar seu desempenho, antenas de abertura são usualmente utilizadas junto a refletores, possibilitando maior diretividade e ganho. A Figura 3.10 ilustra tipos comuns de antenas de abertura.

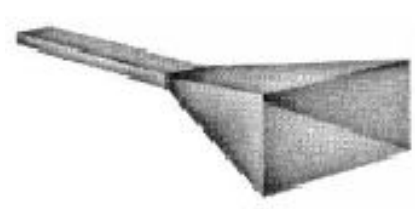

corneta piramidal

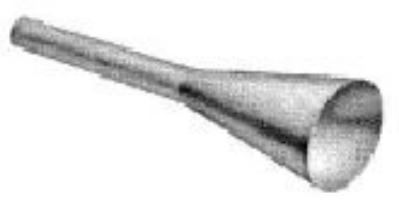

corneta cônica

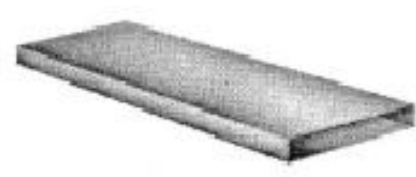

guia de onda retangular

Figura 3.10 - Configurações de antenas de abertura

\subsection{Antenas em sistemas MIMO}

A telefonia móvel talvez seja o serviço em que os sistemas MIMO encontram mais possibilidades e possuem maior chance de desenvolvimento. Em virtude da multiplicação 
de serviços oferecidos, canais com maior robustez e maiores taxas são necessários, e a tecnologia MIMO vem se apresentando como uma solução interessante para resolver as demandas atuais.

Nos terminais móveis, por muito tempo foram utilizadas antenas do tipo monopolo e espiral, Figura 3.11. A segunda surgiu como alternativa à primeira, visto que era uma solução interessante para a busca de equipamentos cada vez menores.

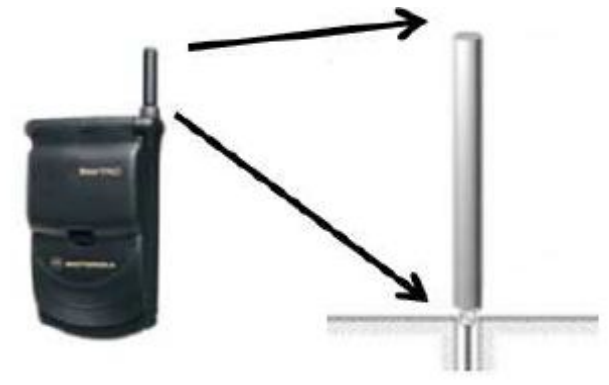

Antena Monopolo

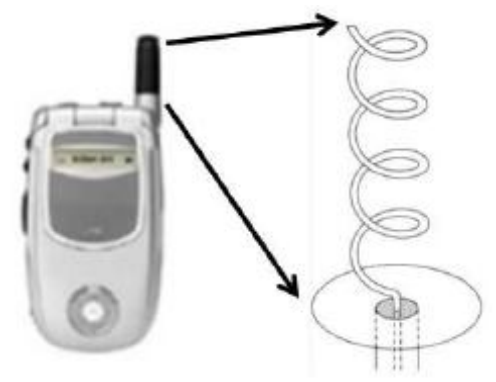

Antena Espiral

Figura 3.11 - Antenas utilizadas na telefonia celular

A combinação de mais de uma antena monopolo, mais de uma antena espiral ou de antenas diferentes começou a ser utilizada para que um mesmo aparelho funcionasse em diferentes faixas de frequência.

Embora tenha atendido momentaneamente a demanda por portabilidade de aparelhos móveis, as antenas espirais acabaram perdendo espaço para as atualmente predominantes no mercado, as PIFA's (Planar Inverse F-Antennas - Antenas F Planas Inversas), Figura 3.12(a).

Caracterizadas por serem estruturas que possuem antenas com terminais curto circuitados em um "plano de terra" por um pino que permite transmitir com tamanhos de antenas muito menores para uma faixa fixa de frequência, as PIFA's são internas aos aparelhos, o que evita danos causados pela exposição e permite aparelhos celulares cada vez mais portáteis. Esse tipo de antena também tem lóbulos traseiros menores, o que significa que elas transmitem menos potência para direções indesejadas, reduzindo assim a energia eletromagnética absorvida pela cabeça do usuário e melhorando seu desempenho [9]. 
Como alternativa às PIFA's, o Doutor Yongho Kim, do Departamento de Engenharia Elétrica e Eletrônica, da Academia de Defesa Nacional de Yokosuka, Japão, apresentou estudos sobre a LFMA (L-Folded Monopole Antenna - Antena Monopolo Dobrada em L), Figura 3.12(b), que serviu de inspiração para a IFMA (I-Folded Monopole Antenna Antena Monopolo Dobrada em I), que é o objeto de análise deste trabalho e será considerada em detalhes no Capítulo 5.

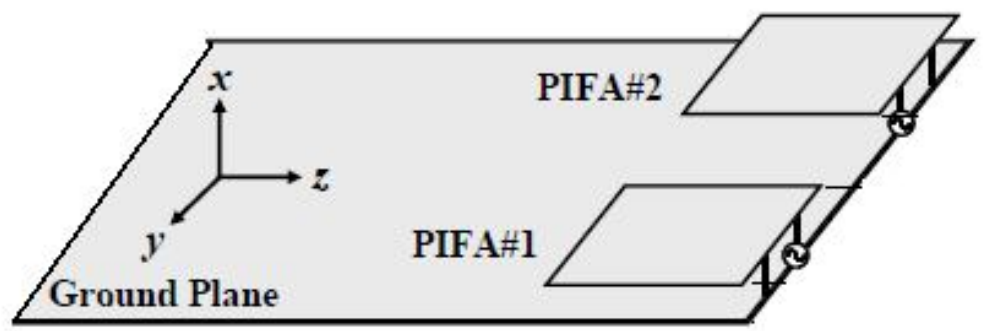

(a)

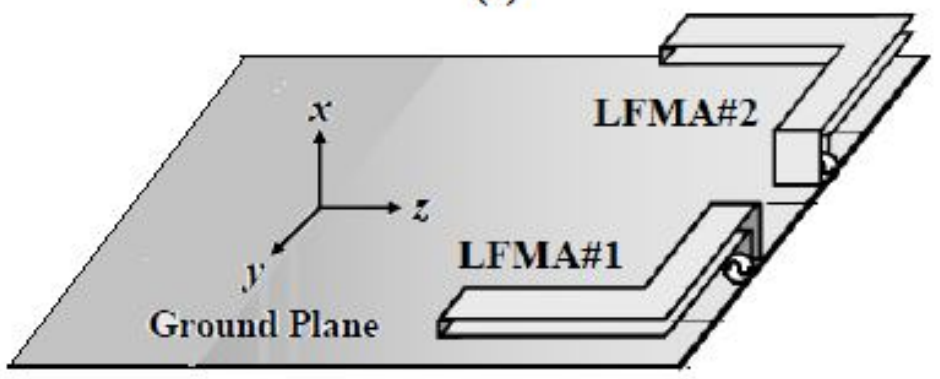

(b)

Figura 3.12 - Exemplos de PIFA e LFMA 


\section{PROJETO DE MÚLTIPLAS ANTENAS}

\subsection{Metodologia}

Como visto no capítulo anterior, existem diversos parâmetros que devem ser levados em consideração no projeto de antenas. Para a obtenção de resultados precisos desses parâmetros, faz-se necessária a solução das equações de Maxwell. Entretanto, diante da complexidade da solução analítica de tais equações, a utilização de métodos numéricos torna-se bastante interessante. Para a simulação das estruturas apresentadas neste trabalho, foi utilizado o software FDTDStudio que faz uso do Método das Diferenças Finitas no Tempo para a solução das equações de Maxwell no domínio do tempo [10].

No projeto de sistemas e estruturas com múltiplas antenas, a impedância mútua entre as antenas é vista como um dos principais desafios, uma vez que modifica os parâmetros de radiação delas e pode comprometer o sistema projetado. Diante desse desafio, foi necessário testar a validade do software FDTDStudio em sistemas com mais de uma antena.

A validação do software foi realizada através de simulações de estruturas mais simples, cujo resultado teórico de acoplamento entre as antenas já era conhecido. Comparados os resultados teóricos com os obtidos através das simulações, foi possível prosseguir com a análise de estruturas mais complexas, objetos de estudo deste trabalho.

\subsection{Validação do Software FDTDStudio}

A impedância mútua entre duas antenas é dada por [7]

$$
Z_{21 m}=R_{21 m}+j X_{21 m}
$$

em que $R_{21 m}$ é a resistência e $X_{21 m}$ é a reatância que a antena 2 provoca na antena 1 . Se as antenas em questão forem dois dipolos de meia onda $(\lambda / 2)$ paralelos, posicionados lado a lado, os parâmetros de resistência e reatância mútuas serão dados por 


$$
\begin{aligned}
& R_{21 m}=\frac{\eta}{4 \pi}\left[2 C_{i}\left(u_{0}\right)-C_{i}\left(u_{1}\right)-C_{i}\left(u_{2}\right)\right] \\
& X_{21 m}=-\frac{\eta}{4 \pi}\left[2 S_{i}\left(u_{0}\right)-S_{i}\left(u_{1}\right)-S_{i}\left(u_{2}\right)\right]
\end{aligned}
$$

em que $\eta=120 \pi$ é a impedância intrínseca do espaço livre, as funções $C_{i}$ e $S_{i}$ são dadas por

$$
\begin{gathered}
C_{i}(x)=\int_{-\infty}^{x} \frac{\cos (\tau)}{\tau} d \tau \\
S_{i}(x)=\int_{0}^{x} \frac{\sin (\tau)}{\tau} d \tau
\end{gathered}
$$

e os parâmetros

$$
\begin{aligned}
& u_{0}=k d \\
& u_{1}=k\left(\sqrt{d^{2}+l^{2}}+l\right) \\
& u_{2}=k\left(\sqrt{d^{2}+l^{2}}-l\right)
\end{aligned}
$$

sendo $k=2 \pi / \lambda$ o número de onda; $d$, a distância e $l$ o comprimento do dipolos, conforme Figura 4.1 .

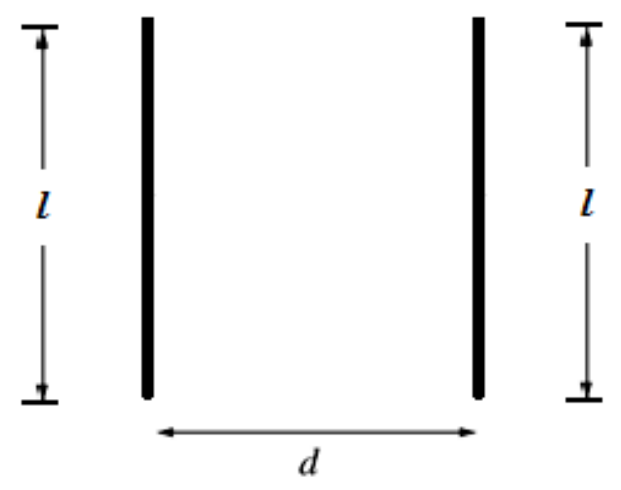

Figura 4.1 - Dois dipolos paralelos, posicionados lado a lado 
Com o intuito de verificar a coerência dos resultados apresentados pelo software FDTDStudio para sistemas com mais de uma antena, a configuração de antenas ilustrada na Figura 4.1 foi simulada para diferentes valores de $d$.

Os dipolos utilizados na simulação, Figura 4.2, tem comprimento $l=0,46 \mathrm{~m}$ e tiveram seus resultados comparados com os resultados esperados para um dipolo de $l=0,5 \mathrm{~m}$. Essa diferença de comprimentos aconteceu porque um dipolo simulado de $l=0,5 \mathrm{~m}$ não atingia a ressonância em sua frequência de operação, $\mathrm{f}=300 \mathrm{MHz}$, uma vez que as equações (4.2) e (4.3) descrevem os valores de impedância de forma analítica, enquanto o software FDTDStudio calcula numericamente tais valores. Assim, um dipolo de $l=0,46 \mathrm{~m}$, alimentado por uma fonte gaussiana derivada com freqüência centralizada em $300 \mathrm{MHz}$, atinge a ressonância próximo à frequência de $300 \mathrm{MHz}$, equivalendo-se a um dipolo de $l=0,5 \mathrm{~m}$ ideal.

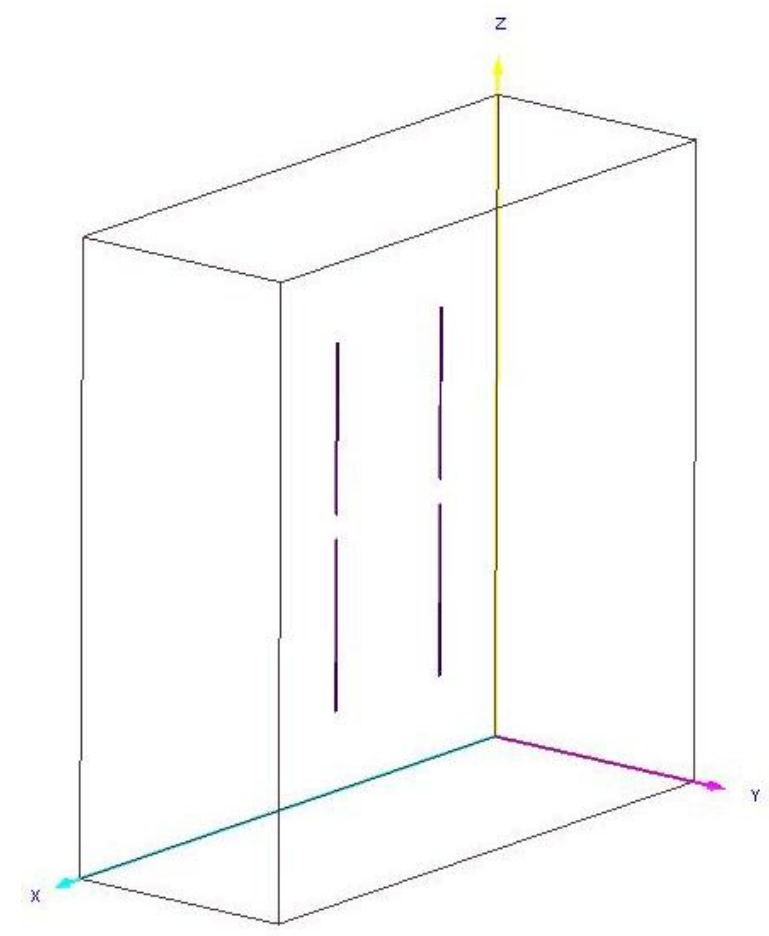

Figura 4.2 - Dois dipolos paralelos na interface do FDTDStudio

Os valores obtidos por meio da simulação foram comparados com os valores teóricos, conforme do gráfico da Figura 4.3, elaborado com o uso do software Matlab, ferramenta também utilizada para o cálculo dos valores teóricos de impedância. De acordo 
com as curvas traçadas na Figura 4.3, é possível concluir que o software FDTDStudio é eficaz para simulações de projeto com múltiplas antenas, uma vez que os valores por ele fornecidos estão coerentes com os valores teóricos.

As Figuras 4.4 a 4.6 comparam os parâmetros de impedância, radiação na frequiência de $300 \mathrm{MHz}$ e perdas de retorno para as situações de dipolo isolado e de dois dipolos separados pela distância $d=0,2 \lambda$. É possível perceber que a impedância varia mais suavemente no caso de dois dipolos separados, enquanto os diagramas quase não sofreram alterações em nenhum dos três planos.

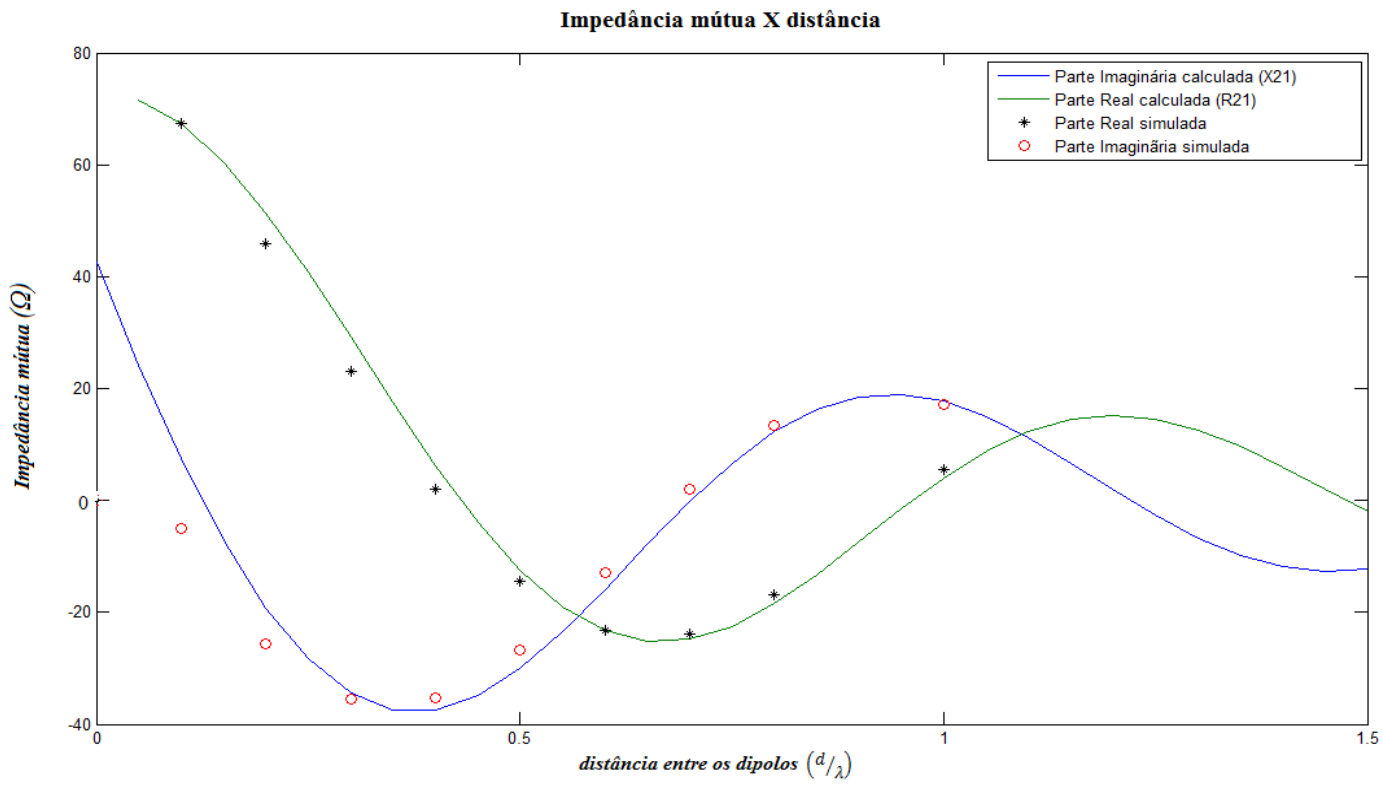

Figura 4.3 - Valores simulados e calculados de Impedância Mútua

Dipolo Isolado

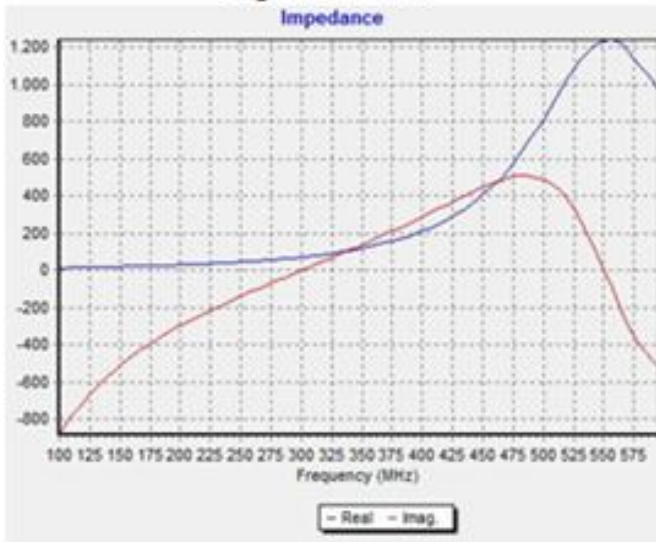

2 dipolos a $d=0,2 \lambda$

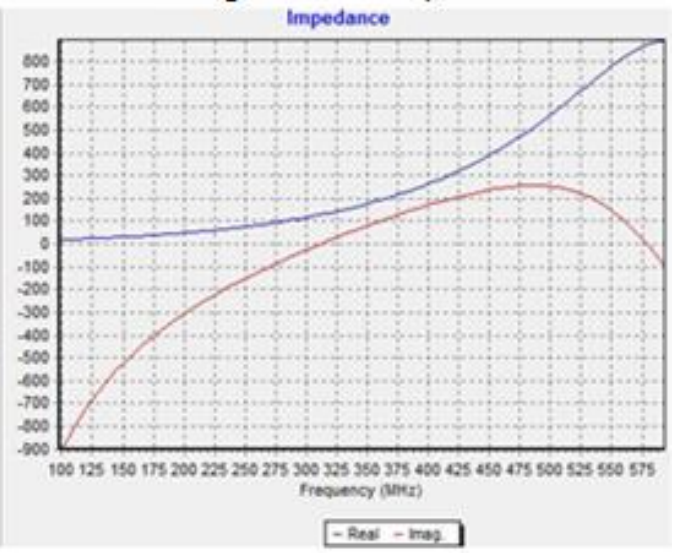

Figura 4.4 - Impedância de dipolo isolado e de dipolos separados por $d=0,2 \lambda$ 
Dipolo Isolado

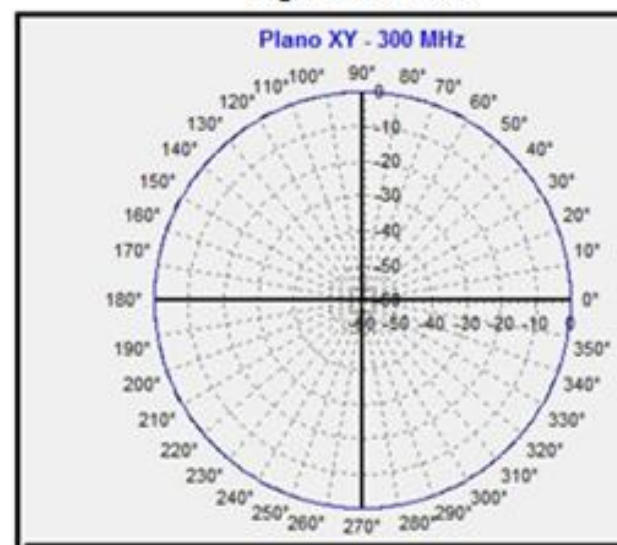

Plano ZX - $300 \mathrm{MHz}$

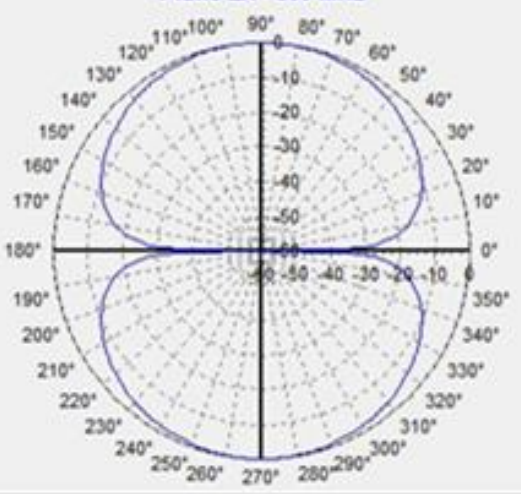

Plano $\mathrm{YZ}$ - $300 \mathrm{MHz}$

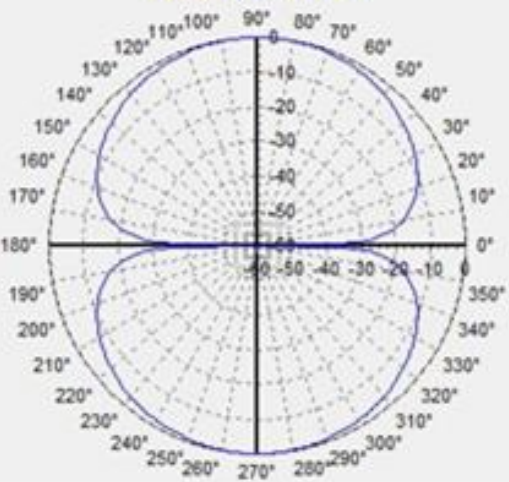

2 dipolos a $d=0,2 \lambda$

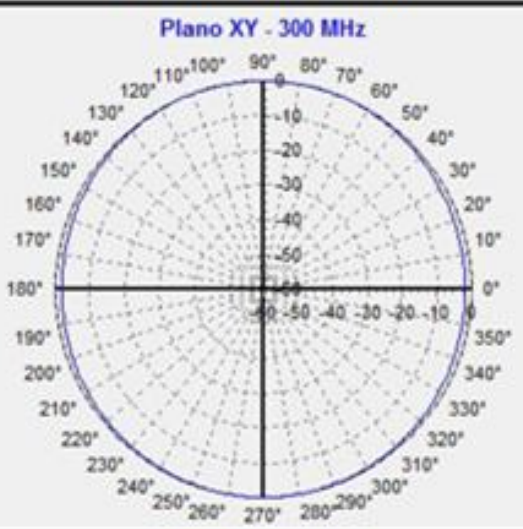

Plano $\mathrm{ZX}-300 \mathrm{MHz}$

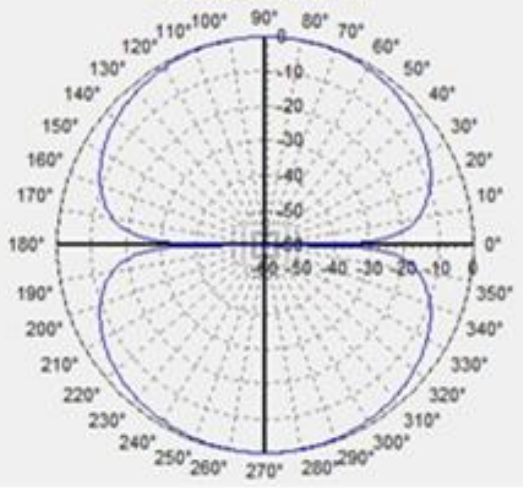

Plano $\mathrm{YZ}$ - $300 \mathrm{MHz}$

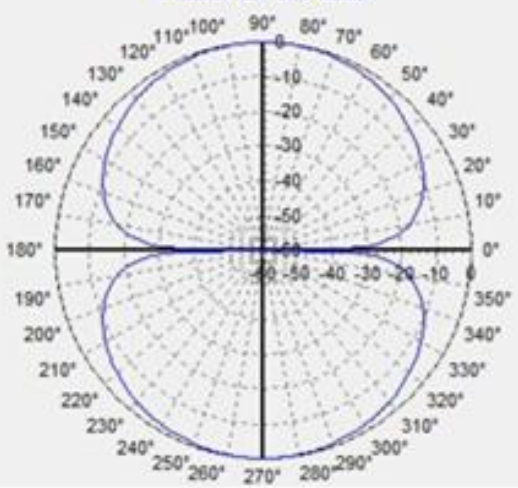

Figura 4.5 - Diagramas de radiação de dipolo isolado e de dipolos separados $d=0,2 \lambda$ 


\section{Dipolo Isolado}

$\$ 11$

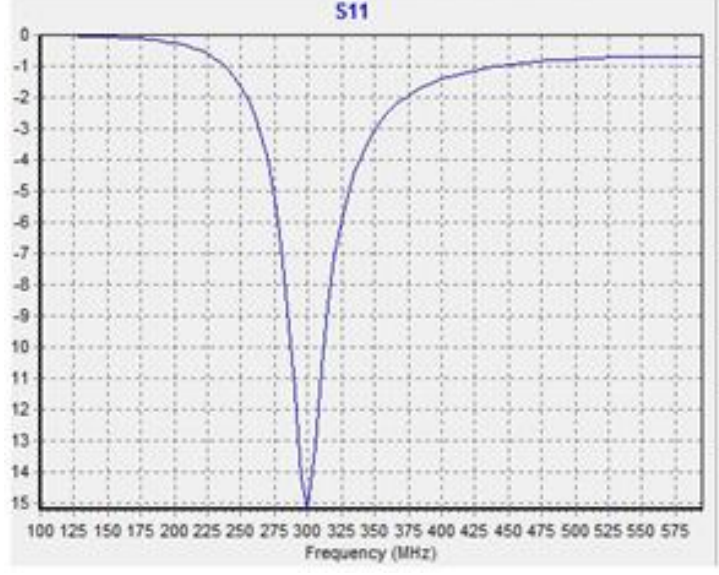

2 dipolos a $d=0,2 \lambda$

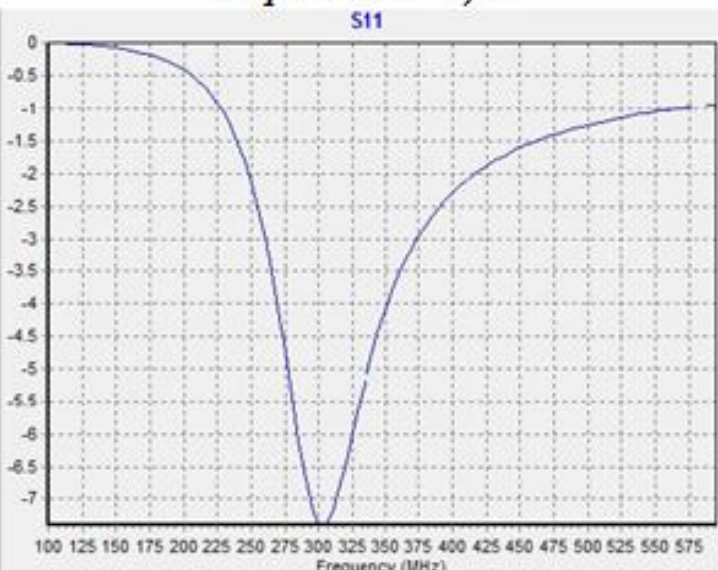

Frequency (MHz)

Figura 4.6 - Perdas de retorno para dipolo isolado e para dipolos separados por $d=0,2 \lambda$

\subsection{Cubo de Dipolos}

Uma vez constatada a eficácia do software FDTDStudio para a análise de projetos com múltiplas antenas, é importante que se ressalte a importância do conhecimento da matriz de impedância do sistema.

A determinação da matriz de impedância é necessária uma vez que ela é a responsável pela indicação do grau de acoplamento entre as antenas, ou seja, ela contém informações sobre a interferência que as antenas provocam umas nas outras. Através da matriz de impedância, é possível o estudo da impedância total de cada uma das antenas do sistema, tornando viável o estabelecimento de uma relação entre o sinal colocado na entrada da antena e o que é efetivamente transmitido por ela, conforme ilustrado na Figura 4.7, em que $x=\left[x_{1}, x_{2}, \ldots, x_{M}\right]$ representa as tensões das fontes de alimentação, $i=$ $\left[i_{1}, i_{2}, \ldots, i_{M}\right]$ corresponde às correntes, $v_{t}=\left[v_{t 1}, v_{t 2}, \ldots, v_{t M}\right]$ representa as tensões nos terminais das antenas transmissoras, $Z_{s}=\left[Z_{s 1}, Z_{s 2}, \ldots, Z_{s M}\right]$ representa as impedâncias das fontes e $Z_{t}$ representa a matriz de impedâncias.

Dessa maneira, conhecendo a matriz de impedâncias do sistema bem como as impedâncias das fontes e sabendo que $v_{t}=x-Z_{s} i$ e que $v_{t}=Z_{t} i$, é possível relacionar a tensão aplicada com a tensão transmitida através de $v_{t}=\frac{z_{t}}{\left(Z_{t}+Z_{s}\right)} x[11]$. 


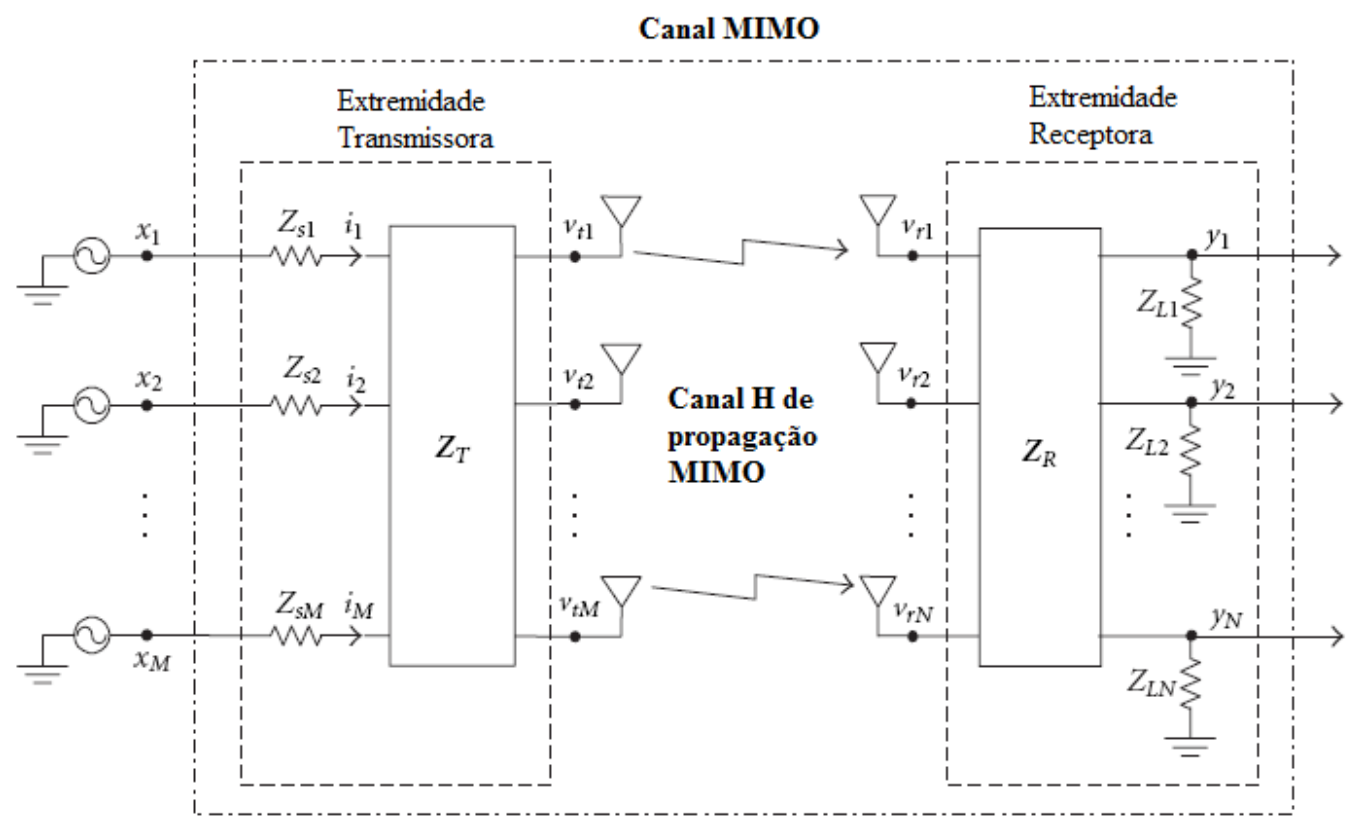

Figura 4.7 - Relação entre tensões na entrada e no terminal dos transmissores

Para ilustrar a determinação de uma matriz de impedâncias, será simulado um cubo de dipolos, por meio do software utilizado como simulador neste trabalho. O cubo de dipolos consiste em um conjunto de antenas dispostas em forma de cubo, com cada uma de suas arestas sendo representada por um dipolo de $l=0,46 \mathrm{~m}$ excitado novamente por uma fonte gaussiana derivada, Figura 4.8.

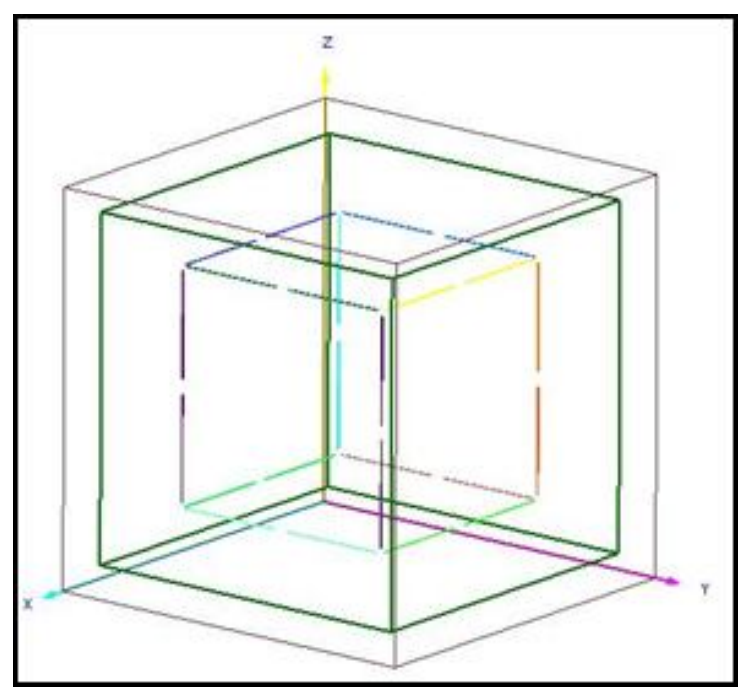

Figura 4.8 - Cubo de dipolos 
Se considerados os casos com e sem acoplamento entre as antenas, o ganho médio e a capacidade do canal são menores para a situação com acoplamento, quando os lados do cubo possuem comprimento menor que $l<0,3 \lambda$, pois, para esses comprimentos, o acoplamento mútuo diminui a SNR nas antenas transmissoras. Para comprimentos maiores, a capacidade do sistema aumenta junto com o volume do conjunto de antenas, deixando de ser relevante o efeito do acoplamento mútuo. Sendo assim, o ponto de operação em que $l<0,3 \lambda$ torna-se um ponto interessante para análise. Entretanto, o cubo de dipolos foi simulado com o intuito de exemplificar a determinação da matriz de impedâncias, e mais informações sobre tal arranjo de antenas podem ser encontradas em [12].

Assim, como os dipolos simulados possuem o comprimento $l=0,46 \mathrm{~m}$, a matriz de impedância foi determinada para a frequência de $196 \mathrm{MHz}$, em que o comprimento de onda é de 1,53 metros e a condição de $l=0,3 \lambda$ é satisfeita.

O primeiro passo da simulação foi determinar a impedância própria de um dipolo, simulando-o sozinho. Posteriormente, fixando um dipolo como referência, este foi simulado aos pares com os outros 11 dipolos, conforme Figura 4.9, a fim de determinar, individualmente, o efeito que cada uma das outras antenas dispostas no cubo exercia sobre a antena de referência, ou seja, a impedância mútua de cada uma delas.

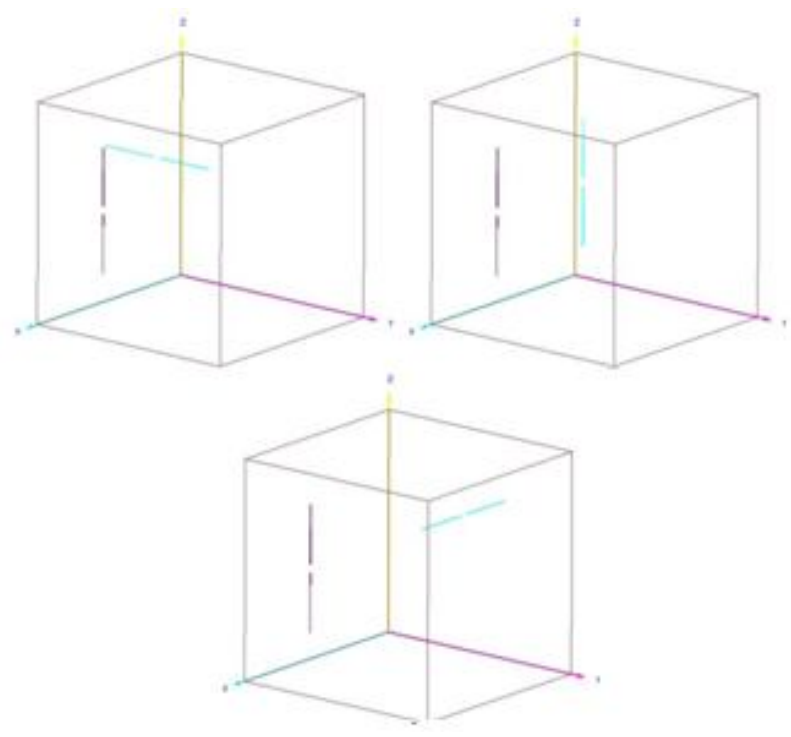

Figura 4.9 - Passos da simulação para determinação da matriz de impedância 
Como todos os dipolos são iguais e foram excitados pela mesma fonte, a matriz de impedância $Z_{t}$, Figura 4.10, é uma matriz simétrica, e seus elementos correspondem a

$$
z_{j i}= \begin{cases}\text { impedância própria }, & \text { se } j=i \\ \text { impedância mútua de } j \text { em } i, & \text { se } j \neq i\end{cases}
$$

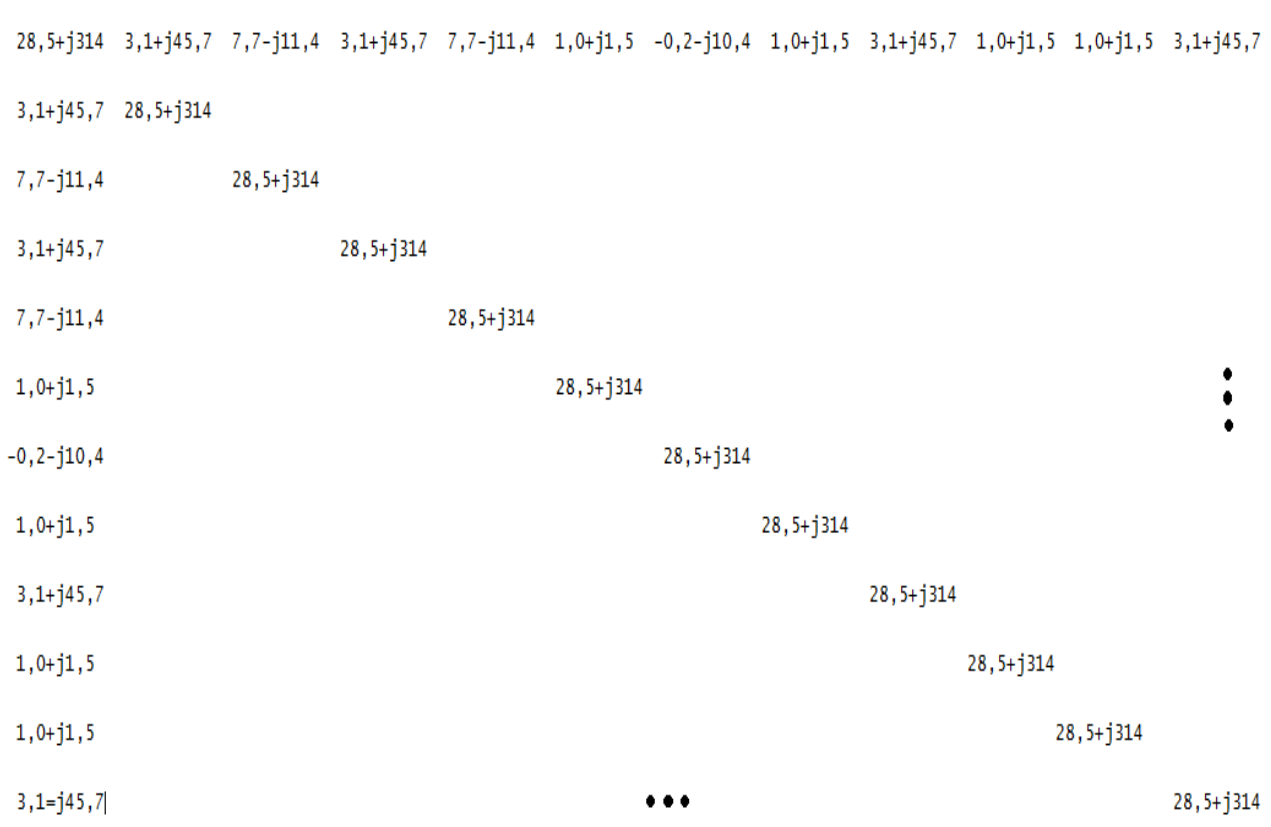

Figura 4.10 - Esboço da matriz de impedância do cubo de dipolos 


\section{CONSTRUÇÃO DA ANTENA IFMA}

\subsection{Simulação}

Este capítulo destina-se a observação prática sobre o que foi estudado acerca de antenas MIMO. Objetivando caracterizar um modelo desejado de múltiplas antenas para emprego em terminais móveis celulares, serão realizadas simulações, construção e análise dos resultados obtidos para determinado tipo de antena.

A antena estudada é uma IFMA (I-Folded Monopole Antenna - Antena Monopolo Dobrada em I) posicionada em um plano de terra com dimensões de 120x45 mm², Figura 5.1 , que deve operar com largura de banda de aproximadamente $200 \mathrm{MHz}$, centralizada em $2 \mathrm{GHz}$. A escolha de tal dispositivo se deu devido à simplicidade de sua geometria, o que favoreceu à construção de um protótipo, bem como devido ao atendimento das necessidades reais de uma antena para dispositivos móveis celulares, tais como tamanho reduzido e frequência de operação bem definida.

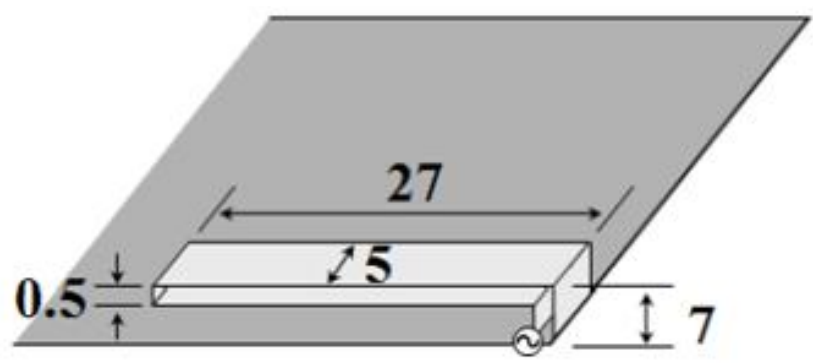

Figura 5.1 - Geometria da antena IFMA, dimensões em mm

A simulação foi realizada por meio do software FDTDStudio, com o intuito de analisar o comportamento da estrutura quanto à sua largura de banda e impedância, verificando seu desempenho para o fim estudado e, posteriormente, compará-la com a mesma estrutura; portando, porém, duas antenas no plano de terra.

Para fins de simulação, a estrutura, ilustrada na Figura 5.2, foi alimentada através de um monopolo de $50 \Omega$ por um pulso gaussiano derivado com frequência central em $2 \mathrm{GHz}$. 
Nestas condições, as curvas de impedância e perdas de retorno encontradas podem ser visualizadas nas Figuras 4.3 e 4.4, respectivamente.

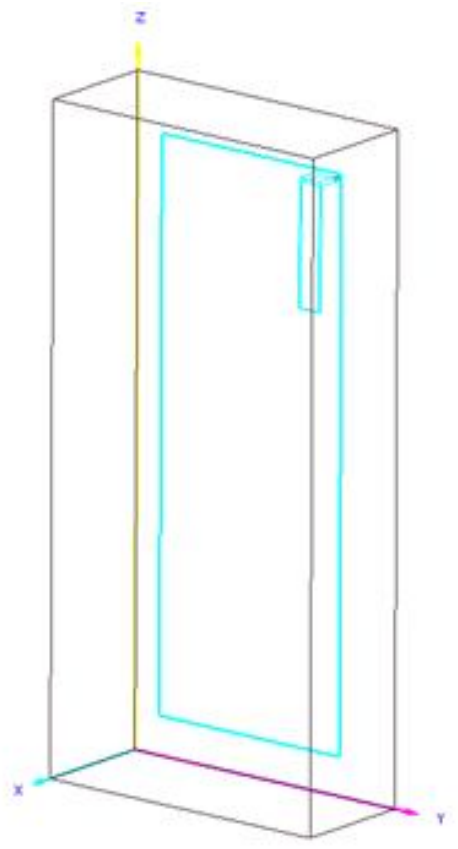

Figura 5.2 - Estrutura da IFM A simples representada da interface do FDTDStudio

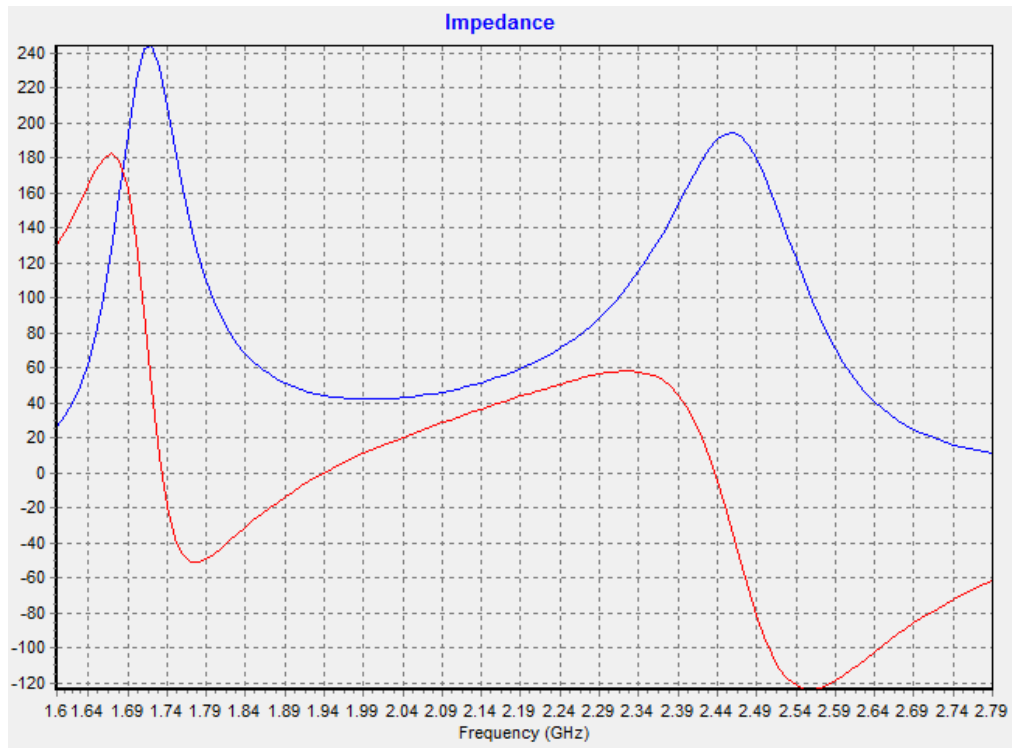

Figura 5.3 - Impedância simulada da IFMA simples 


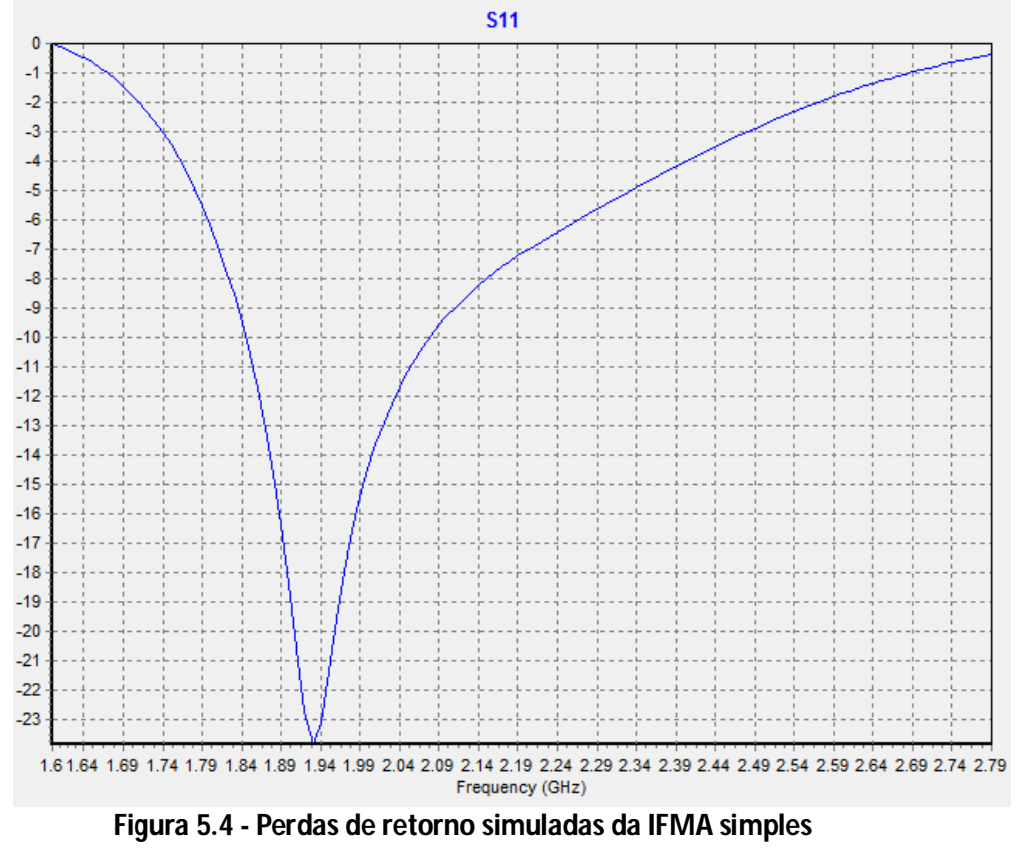

É possível notar, nas curvas obtidas, que a impedância da antena na frequência desejada é de $42+\mathrm{j} 13 \Omega$ e que a antena opera em condições satisfatórias na faixa de 1,84 $\mathrm{GHz}$ a 2,10 GHz, apresentando banda de $260 \mathrm{MHz}$ e frequência central em 1,97 GHz. Tais resultados qualificam a antena a ser utilizada em dipositivos celulares com desempenho até superior às inicialmente impostas.

Comprovada a eficiência da antena IFMA para operação no serviço de telefonia móvel, uma segunda estrutura composta de duas IFMA's posicionadas paralelamente em um plano de terra, Figura 5.5, foi simulada, a fim de verificar seu desempenho e qualificála para substituir sua antecessora, possibilitando ao dispositivo móvel experimentar os benefícios da transcepção em múltiplas antenas.

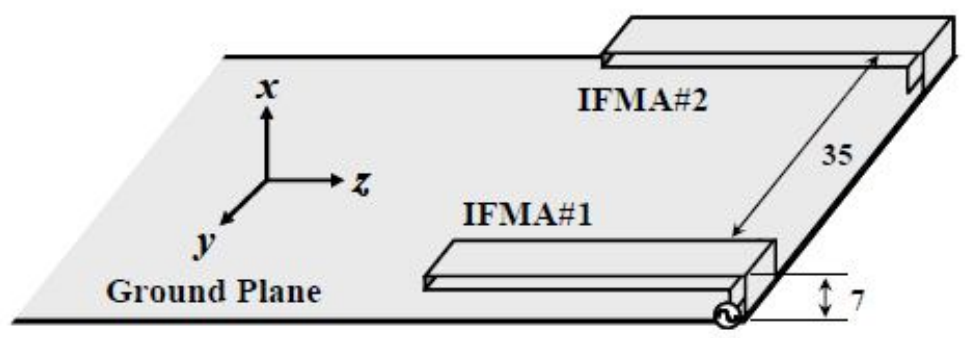

Figura 5.5 - Antena IFM A para sistemas MIMO 
Repetindo a alimentação da simulação anterior para as duas antenas simuladas no software FDTDStudio, Figura 5.6, as curvas obtidas para impedância e perdas de retorno são as apresentadas nas Figuras 5.7 e 5.8, respectivamente.

Observando as curvas obtidas, percebe-se que a característica de impedância segue o mesmo comportamento da apresentada pela estrutura com apenas uma antena, com a curva de resistência levemente deslocada para cima e a curva de reatância levemente deslocada para baixo, resultado do acoplamento mútuo entre as antenas. Como consequência desse acoplamento mútuo, a estrutura apresentou impedância de 52 -j12 $\Omega$ em $2 \mathrm{GHz}$. Considerando a curva de perdas de retorno, é possível constatar que a faixa de operação da antena aumentou consideravelmente, estando situada entre 1,93 e 2,35 GHz, o que representa uma banda de $420 \mathrm{MHz}$ com frequência central em 2,14 GHz.

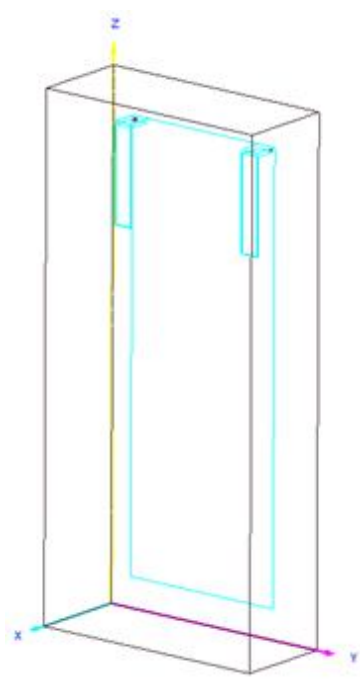

Figura 5.6 - Estrutura da IFM A MIMO representada da interface do FDTDStudio 


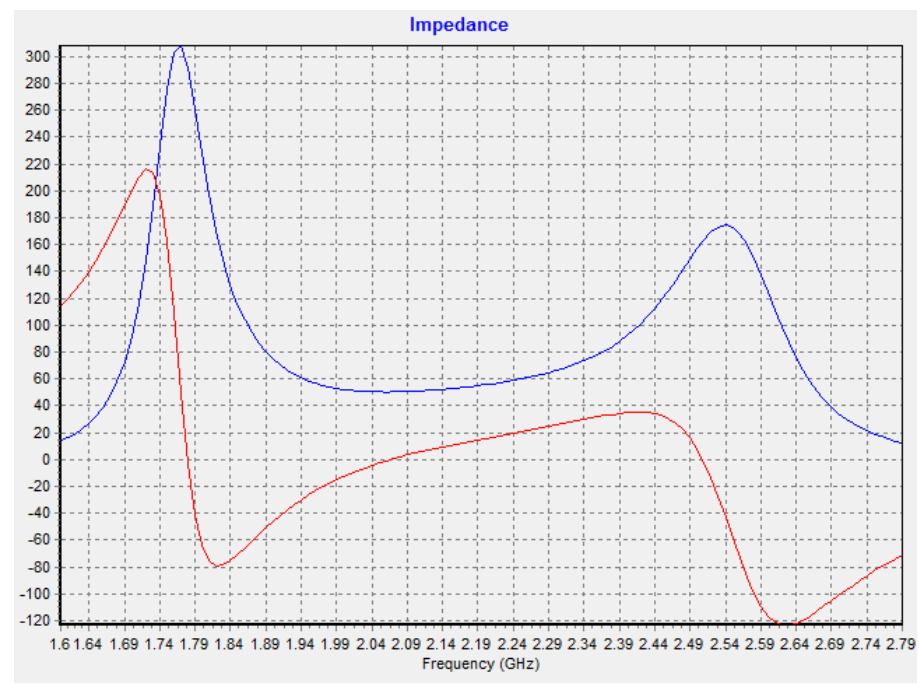

Figura 5.7 - Impedância simulada da IFMA para sistemas MIMO

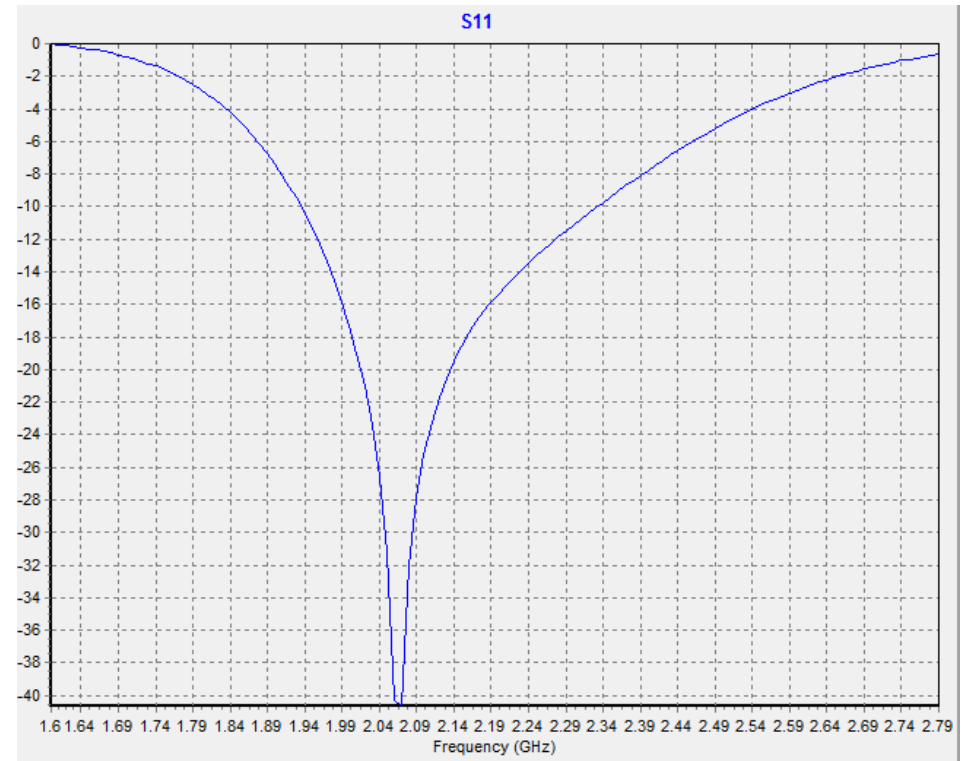

Figura 5.8 - Perdas de retorno simuladas da IFMA para sistemas MIMO

\subsection{Construção da Estrutura}

Para a construção da estrutura ilustrada pela Figura 5.9, foi utilizada uma folha de cobre dobrada e cortada na forma desejada do plano de terra e das antenas. Como dielétrico, a fim de garantir que as antenas ficariam paralelas ao plano de terra, foi utilizado isopor em função da sua semelhança elétrica com o ar, elemento alí presente nas simulações. No corpo das antenas, foi utilizado papel apenas para garantir o isolamento elétrico, uma vez que a pequena separação entre as placas, alinhada à flexibilidade da folha 
de cobre, seria uma possível fonte de curto circuito. A alimentação, idealmente por cabos coaxiais, teve de ser adaptada, com a utilização de dois conectores tipo $\mathrm{N}$ fêmea ligados à antena por simples fios de cobre. Por fim, a antena foi posicionada sobre uma folha de isopor para facilitar seu manuseio e evitar danos à sua estrutura.

Os testes foram realizados por meio do analizador de redes de rádio frequência Agilent RF NETWORK ANALYZER 8714ES, que opera na faixa compreendida entre 300 kHz e 3 GHz, Figura 5.10, do Laboratório de Tratamento de Superfícies e Dispositivos (LTSD), localizado no SG11 da Universidade de Brasília.

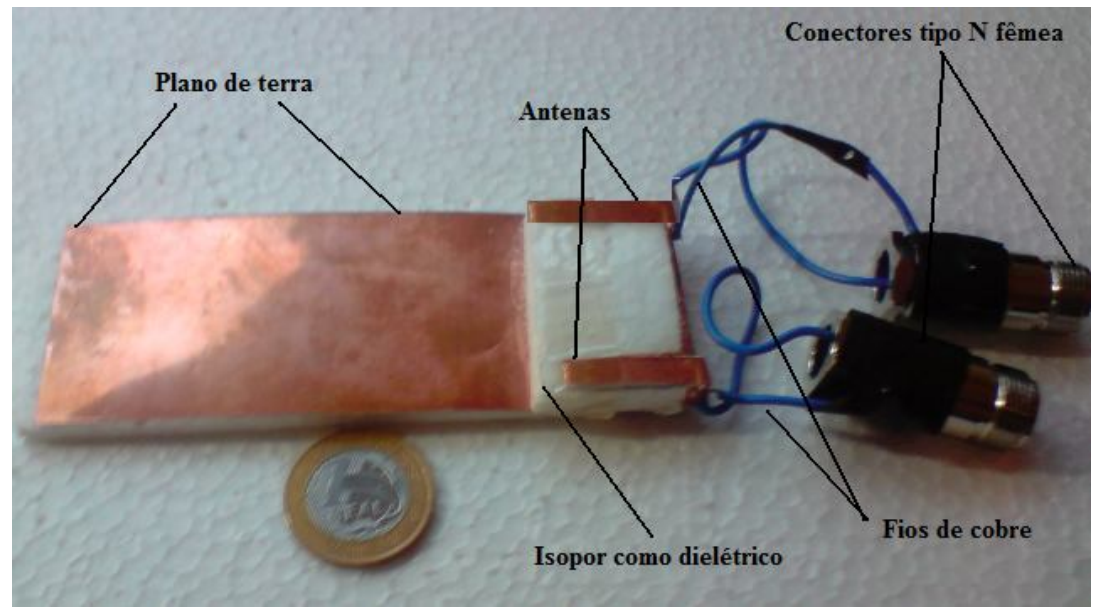

Figura 5.9 - Antena MIMO construída

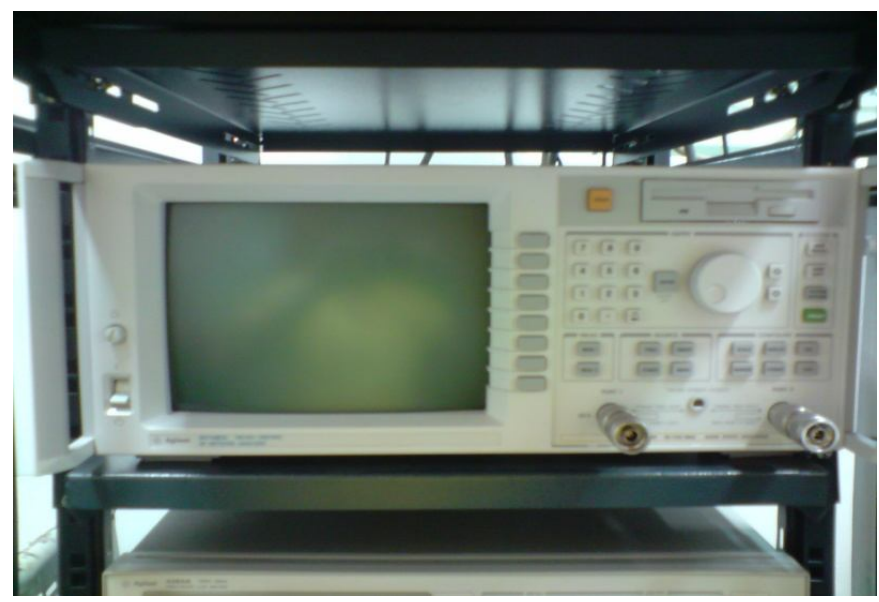

Figura 5.10 - Agilent RF NETWORK ANALYZR 8714ES 


\subsection{Análise dos resultados}

Conectando as duas antenas às entradas do analizador de redes e realizando os ajustes necessários, foi possível obter a curva de perdas de retorno e a carta de Smith, ambas variando em função da frequência. Entretanto, apenas os dados da curva de perdas de retorno foram armazenados com sucesso, sendo necessário que os dados relativos a impedância fossem colhidos manualmente com a variação dos cursores do equipamento. As curvas obtidas são apresentadas, junto às curvas traçadas por meio de simulação, nas Figuras 5.11 a 5.13 .

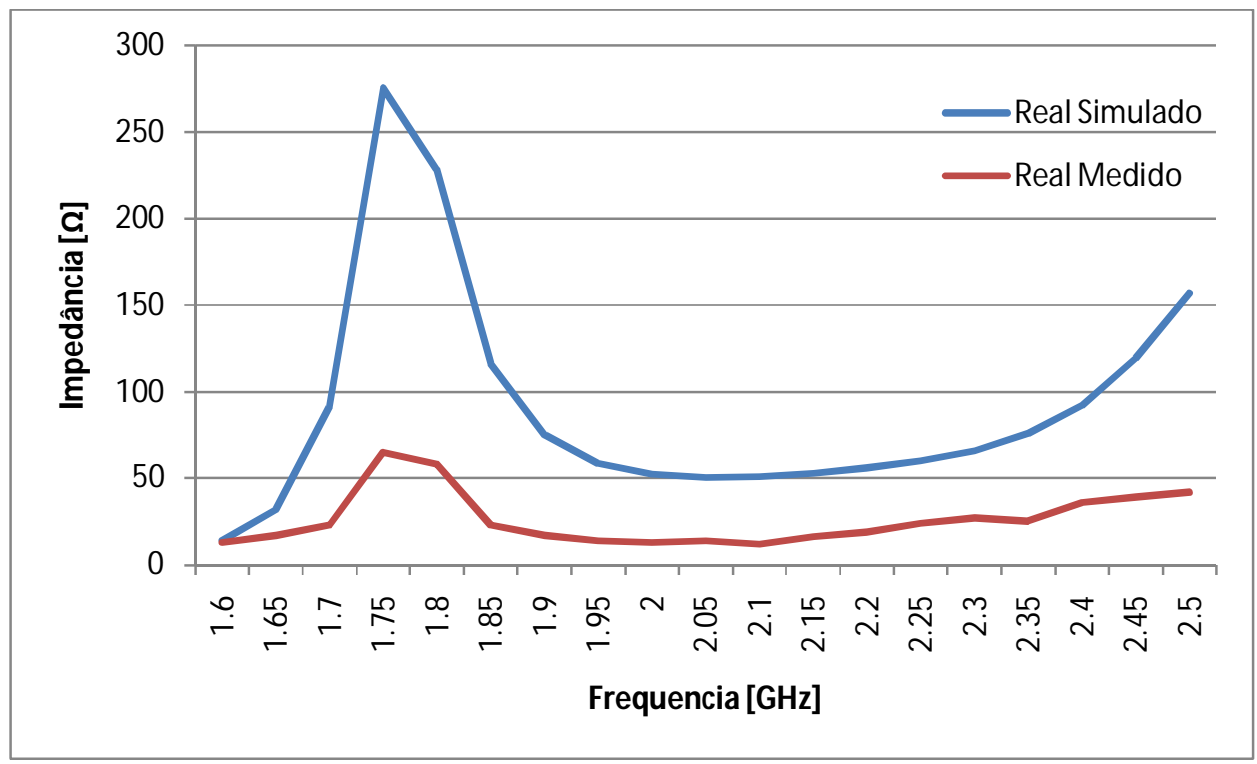

Figura 5.11 - Resistências medida e simulada 


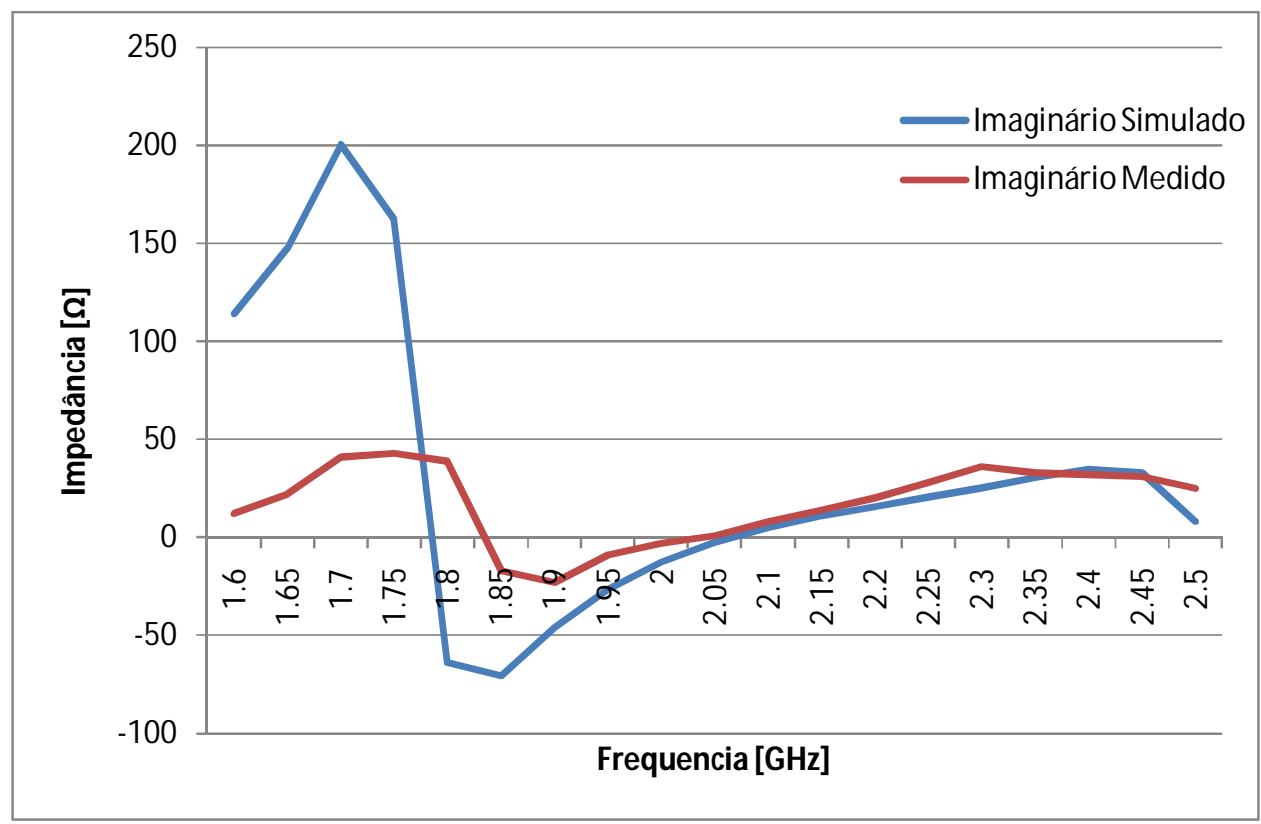

Figura 5.12 - Reatâncias medida e simulada

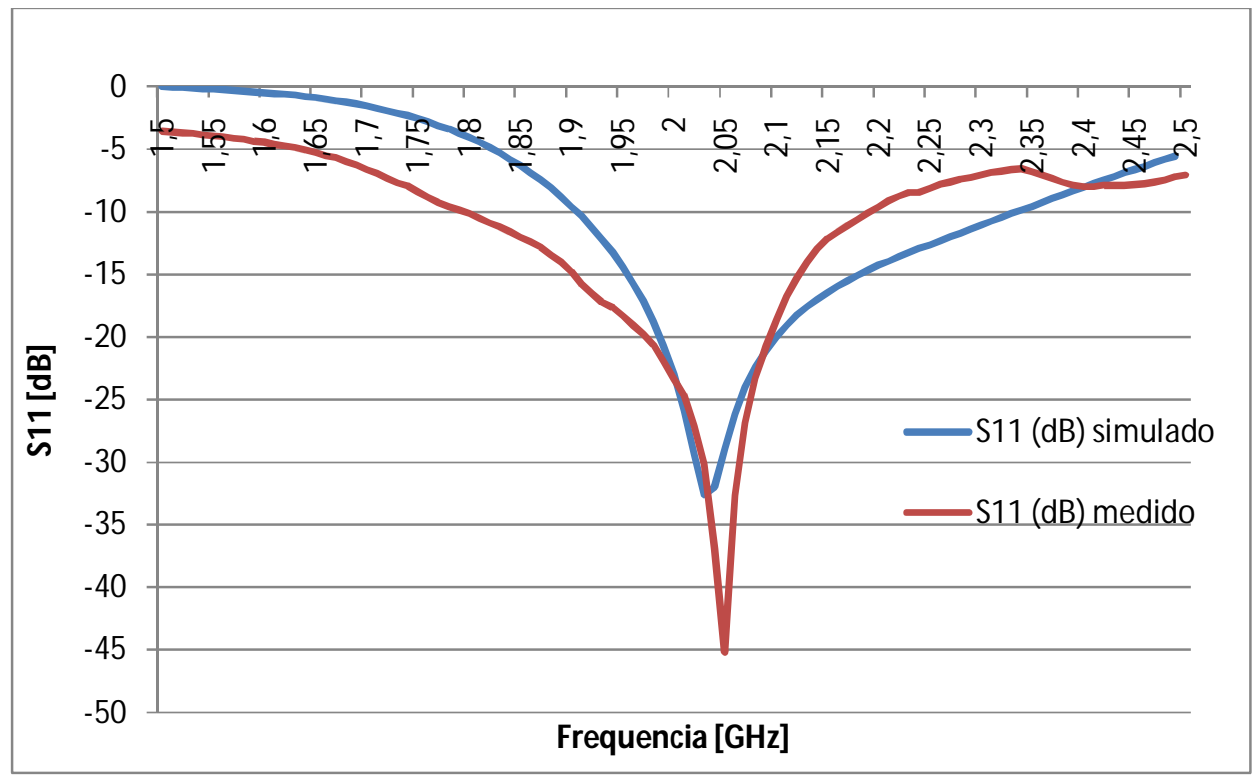

Figura 5.13 - Perdas de Retorno medida e simulada

Nota-se, a partir das curvas de impedância, Figuras 5.11 e 5.12, que os valores obtidos em laboratório não condizem, com os simulados. Tal fato pode ser creditado às condições de construção da antena, em que podemos listar a imprecisão nos cortes e medidas bem como o material precário utilizado e a soldagem arcaica como fonte de erros. Entretanto, a maior fonte de erro talvez seja a forma como a antena foi alimentada ante a impossibilidade de se utilizar cabos coaxiais, uma vez que simples fios de cobre, quando 
operando em frequências da ordem de $2 \mathrm{GHz}$, tornam-se grandes indutâncias parasitas e prejudicam o experimento. Outro aspecto relevante é que, por ser limitado à frequência de $3 \mathrm{GHz}$, o equipamento permitiu apenas que fossem capturados dados relativos ao primeiro harmônico, quando o ideal para a coleta de dados mais fidedignos fosse a análise de frequências até o terceiro harmônico.

Contudo, tanto as curvas de indutância quanto a curva de perdas de retorno medidas, Figura 5.13, embora apresentem amplitudes discrepantes, seguem o padrão das curvas simuladas, apresentando formas de ondas similares às esperadas, o que confere credibilidade e validade aos testes executados. 


\section{CONCLUSÕES E TRABALHOS FUTUROS}

A tecnologia MIMO tornar-se-á cada vez mais presente em sistemas de comunicação sem fio. Neste trabalho, foi possível elucidar quais as vantagens de se ter mais de uma antena transmitindo e recepcionando o sinal, bem como os desafios e as limitações dessa prática, mesmo que ainda haja várias lacunas na determinação exata de algumas propriedades do sistema.

Junto à apresentação de conceitos de antenas, os conceitos expostos sobre a tecnologia MIMO permitiram uma análise do acoplamento mútuo entre antenas e seu comportamento em função da frequência e distância entre os elementos de transmissão, em que constatou-se que estes são aspectos muito importantes de projeto, pois podem ser a diferença entre estruturas em que as antenas proporcionam grandes ganhos ao sistema e estruturas que se interferem de forma destrutiva. Através de simulações, foi possível verificar a validade do software FDTDStudio para projetos de sistemas MIMO ao comparar os resultados por ele apresentados aos resultados demonstrados na bibliografia utilizada. Verificada a eficácia do software, o foco voltou-se para a quantificação e qualificação da influência do acoplamento mútuo em algumas estruturas multi-antenas propostas.

No que concerne à antena testada, pode-se dizer que o objetivo foi alcançado, uma vez que foi construída uma antena uma estrutura para dispositivos móveis celulares portando mais de uma antena e seu funcionamento, mesmo ante as limitações de fabricação, foi condizente com os resultados obtidos em simulações.

Por fim, seguindo o estudo aqui desenvolvido, algumas tarefas ainda podem ser realizadas com o intuito de se obter outros resultados a respeito de canais MIMO e múltiplas antenas, tais como:

- Análise de estruturas que mantenham um volume próximo ao da IFMA, porém contendo mais tranceptores

- Estudo de estruturas posicionadas na outra extremidade do enlace celular que não a do usuário 
- Análise da questão do compromisso entre a ordem de diversidade e o ganho de multiplexação em sistemas MIMO

- Estudos referentes a estimação eficaz do canal que permita que o canal real se aproxime do decomposto idealmente. 


\section{REFERÊNCIAS BIBLIOGRÁFICAS}

[1] ANATEL. Dados de Acessos Móveis em Operação e Unidade da Federação. Disponivel em: <ftp://ftp.3gpp.org/Inbox/2008_web_files/LTA_ Paper.pdf > . Acessado em novembro de 2009.

[2] 3GPP. Evolved Universal Terrestrial Radio Access (E-UTRA) and Evolved Universal Terrestrial Radio Access Network (E-UTRAN); Overall description;. [S.1.], 2008.

[3] Morishita, H. Design and Analysis of Handset MIMO Antenna by Using Folded Monopole Antennas. Departamento de Engenharia Elétrica e Eletrônica, Academia de Defesa Nacional, Yokosuka, Japão, 2008.

[4] Goldsmith, A. Wireless Communications, pp. 299-318. Cambridge University, 2005

[5] Andrews, J.G.; Ghosh, A.; Muhamed, R. Fundamentals of WIMAX: Understanding Broadband Wireless Networking, pp. 140-194. Prentice Hall, 2007.

[6] IEEE Transactions on Antennas and Propagation, vols. AP-17, $\mathrm{n}^{\circ} 3$, Maio 1969 e AP22, no 1, Janeiro 1974.

[7] Balanis, C.A. Antenna Theory: Analysis and Design. República de Singapura: Wiley Interscience, 1982.

[8] Esteves, L. C. Antenas: Teoria básica e aplicações, pp. 63-37. São Paulo: McGrawHill, 1980.

[9] Wong, K.L. Planar Antennas for Wireless Communications. Nova Jersey: Wiley Interscience, 2003.

[10] Picanço, R.P. Desenvolvimento de uma interface integrada ara o projeto e análise de antenas utilizando o método das diferenças finitas no domínio do tempo (FDTD). Dissertação de mestrado, Departamento de Engenharia Elétrica, Universidade de Brasília, 2006.

[11] Yang,Y.; Blum R. S.; Sfar, S. Antenna Selection for MIMO Systems with Closely Spaced Antennas. EURASIP Journal on Wireless Communications and Networking, 2009.

[12] Getu, B.N.; Janaswamy, R. The Effect of Mutual Coupling on the Capacity of the MIMO Cube. IEEE Antenas and Wireless Propagation Letters, Vol. 4, 2005. 